\title{
WHAT HAPPENS TO CELLULOSIC FIBERS DURING PAPERMAKING AND RECYCLING? A REVIEW
}

\author{
Martin A. Hubbe, ${ }^{*}$ Richard A. Venditti, and Orlando J. Rojas \\ Both reversible and irreversible changes take place as cellulosic fibers \\ are manufactured into paper products one or more times. This review \\ considers both physical and chemical changes. It is proposed that by \\ understanding these changes one can make better use of cellulosic \\ fibers at various stages of their life cycles, achieving a broad range of \\ paper performance characteristics. Some of the changes that occur as a \\ result of recycling are inherent to the fibers themselves. Other changes \\ may result from the presence of various contaminants associated with \\ the fibers as a result of manufacturing processes and uses. The former \\ category includes an expected loss of swelling ability and decreased \\ wet-flexibility, especially after kraft fibers are dried. The latter category \\ includes effects of inks, de-inking agents, stickies, and additives used \\ during previous cycles of papermaking.
}

Keywords: Paper recycling, Drying, Deinking, Hornification, Inter-fiber bonding, Refining, Fines, Fiber length, Conformability

Contact information: Department of Forest Biomaterials Science and Engineering, Box 8005, North Carolina State University, Raleigh, NC 27695-8005, USA; *Corresponding author: hubbe@ncsu.edu

\section{INTRODUCTION}

Cellulosic fibers can change significantly when formed into a wet web of paper and subsequently subjected to such processes as pressing, drying, printing, storage, repulping, and deinking. Some of the changes can be subtle. Often it is possible to substitute recovered fibers in place of virgin fibers used for the production of paper or paperboard. On the other hand, characteristic differences between recycled fibers and virgin fibers (fresh from pulping wood, not recycled) can be expected; many of these can be attributed to drying. Drying is a process that is accompanied by partially irreversible closure of small pores in the fiber wall, as well as increased resistance to swelling during rewetting. Further differences between virgin and recycled fibers can be attributed to the effects of a wide range of contaminating substances. Important progress in understanding the changes that occur when fibers are made into paper, and then recycled, has been reviewed (Howard 1990, 1995; Laivins and Scallan 1993; Nazhad and Paszner 1994; Howarth 1994; Phipps 1994; Ackermann et al. 2000; Shao and Hu 2002; Hubbe et al. 2003b; Hubbe and Zhang 2005; Nazhad 2005). To provide context, this review will begin by describing some characteristics of papermaking fibers just before the forming process and then will discuss issues relevant to the recycling process and its effect on fiber properties. 


\section{THE “ACTIVATED” NATURE OF FRESHLY PREPARED FIBERS}

Several processes must take place before the cellulosic fibers in wood are in a form suitable for the production of paper. The net effect of the processes to be outlined below has been described by the word "activation" (see Stürmer and Göttsching 1979). "Activation" implies that the material is converted into a form that is, in some respects, more susceptible to changes, including those associated with formation of bonds between adjacent fibers when a wet web of paper is dried. The concept of an activated state of the cellulosic material also can be helpful when discussing various effects associated with papermaking and conversion, storage, use and recycling (including repulping, and deinking operations) of paper and paperboard. As will be discussed, the net effect of these latter processes, especially recycling, can be understood in terms of a "deactivation" of the fiber material (Nazhad and Paszner 1994). As some researchers have remarked, many factors that improve bonding between cellulosic fibers during a given cycle of papermaking unfortunately tend to reduce the capability of the fibers to form strong interfiber bonds again when the recovered paper is made into recycled paper (Pycraft and Howarth 1980b; Weise 1998). Increased refining and increased wet-press pressure are key examples.

Paper can be defined as a sheet-like material that is formed from individualized fibers by the removal of water. Wood is the most important source, at present, of such fibers. Thus, the separation of wood into its component fibers, i.e. "pulping," might be considered to be the first step in their "activation." Billosta et al. (2006) compared the ultrastructural details of papermaking pulps that were prepared in different ways, i.e. chemical, mechanical, thermomechanical or a combination thereof (Gullichsen and Fogelholm 1999; Sundholm 1999). It was found that fibers experience extensive delamination, as well as the formation of fibrils at their surfaces. These effects occur to different degrees, depending on the type of pulping process used. Microscopic observations provide clear evidence that fibers are present in pulp in the form of layered structures with domains of hemicellulose and lignin, which are present to different extents, depending on the type of pulp (Xu 2006; Li 2004a, 2004b, 2005, 2006; Shao, 2006).

In terms of physical attributes, one of the most important ways in which the individualized fibers in pulp are different in comparison to the wood from which they originated is the great increase in surface area per unit of dry mass, i.e. specific surface area. Studies have shown that the specific surface area of never-dried pulp fibers can be more than 100 square meters per gram (Stone and Scallan 1966). Mechanical pulping processes tend to separate the fiber material into a wide range of sizes, due to partial breakage of many of the individual tracheids and libriform fibers. By contrast, chemical pulping operations tend to leave the fibers relatively intact.

\section{Chemical Pulping as a Means of Rendering Fibers More Active}

One of the ways in which pulping operations can render fibers more susceptible to forming bonds with each other is by increasing the free energy of their surfaces. As reviewed by others, the free energy of a surface can be evaluated by testing the contact angles of those surfaces with selected liquids (Chatterjee et al. 1991; Jacob and Berg 1993; Whang and Gupta 2000; Shen et al. 2000; Tze and Gardner 2001b), as well as by 
inverse gas chromatography techniques (Felix and Gatenholm 1993; Tze and Gardner 2001b; Santos et al. 2001) in which one evaluates the interactions of the solid phase (fibers) with a series of chemicals in the gas phase. Such studies have shown that the removal of relatively hydrophobic lignin and natural resins from wood can greatly increase the free energy of cellulosic surfaces. Cellulosic fibers that are derived from mechanical vs. chemical pulping can contrast sharply with respect to surface chemical composition and structure. The surfaces of fibers formed by chemical (e.g., kraft or sulfite) processes will tend to have higher free energy in comparison to fibers that were separated from each other mainly by mechanical means (Backström et al. 1999). Because mechanical pulping methods, such as thermomechanical pulping (TMP), typically separate fibers from each other at the lignin-rich middle lamella (Kibblewhite 1983; Gregersen et al. 1995), the resulting external surfaces of TMP fibers tend to be rich in lignin, relatively non-compliant, and somewhat hydrophobic. By contrast, removal of lignin and extractives during kraft pulping, and also by any subsequent bleaching and associated washing stages, yields fiber surfaces that are rich in carbohydrates.

Another way in which kraft or sulfite pulping tends to activate never-dried cellulosic fibers is by increasing the size and net volume of submicroscopic pore spaces within the cell walls. Such changes have been quantified by means of solute exclusion experiments (Stone and Scallan 1968; Berthold and Salmén 1997), by determination of the water retention (Jayme and Büttel 1964), and by various other methods (Li et al. 1993; Alince and van de Ven 1997; Andreasson et al. 2003).

Solute exclusion tests are carried out by exposing known amounts of fibers to known amounts of solutions containing given levels of sugar-like polymers. The polymers have different, narrowly-distributed molecular sizes. Experimental results are obtained by measuring the concentrations of sugar in the bulk phase. In cases where the sugar-like molecules are too big to enter the pores in the fiber material, the measured concentrations in the bulk solution will exceed the values that would be expected if the polymers were able to enter the small pores. Such tests have shown that many of the slitlike pores within mechanical pulp fibers tend to be somewhat larger than $1 \mathrm{~nm}$ in thickness, whereas such pores in chemically pulped, but never-dried fibers can be at least $2 \mathrm{~nm}$ to $50 \mathrm{~nm}$ (Stone and Scallan 1968; Berthold and Salmén 1997). The difference is attributed to the selective removal of lignin-rich domains from the fiber material during pulping. Recently this nanoporous nature of fibers was confirmed indirectly by electrokinetic methods (Hubbe 2006a).

Chemical pulping also tends to increase the flexibility and conformability of never-dried fibers (Tam Doo and Kerekes 1982; Paavilainen 1993). One of the most dramatic consequences of such changes is that kraft fibers more readily flatten into a ribbon-like form under compression and shear forces in the wet state. Flexible, ribbonlike fibers tend to form stronger inter-fiber bonding, compared to relatively stiff fibers, in which the open lumen structure may persist during papermaking.

\section{Bond-Activation by Refining}

To further prepare fibers for their role in papermaking, often they are subjected to compression and shearing forces, i.e. they are "refined" (Paulapuro 2000). The goal is to optimize the conditions of refining so that the fibers' wet-conformability, capability of 
bonding together, and tendency to form a bulky or a compact structure is sufficient to meet the requirements of a typical grade of paper.

Kraft fibers usually are refined by one or more passes between a rotor and a stator of a typical refiner. Bunches of fibers within the suspension become squeezed and sheared between the working surfaces of the refiner. As a consequence of this action, parts of the outer layers of fibers unravel, resulting in fibrillated fiber surfaces, as well as detached fines. In addition, delamination within the cell wall tends to render the fibers more flexible when they are still in the wet condition. Though it is well known that the strength of paper can be substantially improved by refining, subsequent loss in inter-fiber bonding potential also can be much larger when (kraft) fibers are refined before they are dried and recycled (Stürmer and Göttsching 1979; Peng et al. 1994).

Fascinating new insights on the effects of kraft pulp refining have been provided by a study that used highly contrasting methods of refining (Kang and Paulapuro 2006). One set of pulp samples was refined under specialized conditions that mainly delaminated the interior structure of the cell walls (internal fibrillation), making the fibers very flexible. The other set was refined under conditions that favored external fibrillation, leaving the bulk of the cell walls relatively unchanged. In both cases the resulting pulps were able to form substantially stronger paper in comparison to unrefined fibers of the same type.

\section{OVERVIEW OF CONDITIONS TO WHICH FIBERS ARE EXPOSED}

As has been shown by many studies, the recycling of cellulosic fibers, especially in the case of chemically pulped fibers, usually is associated with a loss of physical strength properties (Brecht 1947; McKee 1971; Cildir and Howarth 1972; Horn 1975; Koning and Godshall 1975; Cardwell and Alexander 1977; Göttsching and Stürmer 1978a; Yamagishi and Oye 1981; Van Wyk and Gerischer 1982; Ferguson 1992a; Howard and Bichard 1992; Mansito 1992; Klofta and Miller 1993; Laivins and Scallan 1996; Law 1996; Wistara and Young 1999; Jahan 2003; Hubbe and Zhang 2005; Garg and Singh 2006). Significant losses in the bonding potential of recycled fibers has been observed even in cases where the dried and redispersed fiber were refined again to the same level of freeness before they were first dried (Brecht 1947; McKee 1971; Koning and Godshall 1975; Göttsching and Stürmer 1978a; Van Wyk and Gerischer 1982). To discuss the evidence to explain these changes, this section gives a quick overview of the conditions to which papermaking fibers are exposed, not only during the manufacture of paper, but also during its subsequent printing and converting operations, storage, use, repulping, de-inking, and re-refining.

\section{Papermaking}

The moment just before fibers are first formed into paper can be considered as a useful point of reference. As should become increasingly clear from subsequent discussions, kraft and sulfite fibers that have been freshly prepared for the first generation of papermaking are often at the highest state of readiness that they ever will be, in terms of forming strong paper. Though, as will be described, such a statement is not always true 
in the case of mechanical pulp fibers, the reference point is still useful in describing changes in mechanical pulps, as well.

\section{Wet End Additives}

To a large extent, the addition of chemical additives to the wet end of a paper machine can be considered to be a reversible process, with respect to recycling. Many such chemicals, such as cationic starches (Marton 1976; Roberts et al. 1986; Malton et al. 1998), are prepared in such a way that they will tend to remain attached to the cellulosic materials. A substantial proportion of such chemical additives can remain associated with the fibers when they are recycled. It has been shown that highly charged wet-end additives will continue to influence the charge characteristics of papermaking fibers, even after they have been dried and repulped (Grau et al. 1996; Sjöström and Ödberg 1997). Likewise, the effects of hydrophobic sizing treatments may be passed down to subsequent generations of recycled paper (Sjöström and Ödberg 1997). Overviews describing the effects of various papermaking additives have been published elsewhere (Scott 1996; Neimo 1999).

\section{Pressing}

The next event in the papermaking process that affects the quality of cellulosic fibers (including fibers after they are recycled) is passage through a wet-press nip. Various authors observed decreases in the water-holding capacities of fibers that have been subjected to wet-pressing conditions (Robertson 1964; Carlsson and Lindström 1984). Scallan (1998) attributed such changes to somewhat irreversible formation of hydrogen bonds between cellulosic surfaces within void spaces of the cell wall that become pressed together due to the applied force. The theory is that semi-crystalline regions of hydrogen bonds form on the contacting pressed surfaces. Scallan (1998) also proposed that the process involves swollen hemicellulosic material as a kind of natural dry-strength agent. Weise and Paulapuro 1996 used laser confocal microscopy and swelling measurements and reported that irreversible hornification (meaning a loss of swelling when the fibers are rewetted) began above solids contents of 30-35\%.

\section{Drying}

Much of the subsequent discussion in this article will deal with effects of drying, so only a brief description needs to be given here. As will be shown later, it can be useful to distinguish between two aspects of what happens when paper is dried. On the one hand, the wet paper already becomes hot when the web still contains substantial moisture (heat-transfer dominated stage). On the other hand, water evaporation makes the paper web dryer (mass-transfer-dominated stage).

Temperatures and durations of time associated with the drying of paper can be expected to vary widely, depending on the basis weight of the product, the speed of the paper machine, and other paper machine design and operation parameters. Conventional drying on paper machines takes place under atmospheric pressure. For this reason, the temperature of the paper will tend to remain at the boiling point or lower, as long as liquid water remains within the pore spaces adjacent to the sheet's surface (Garvin and Pantaleo 1976). However, due to the dynamic nature of the drying process, and also due 
to above-boiling surface temperatures of dryer can surfaces, it may be possible to measure temperatures at paper surfaces that are above the boiling point of water, especially when the web is approaching a dry condition.

\section{Calendering}

The calendering of paper can be defined as a process whereby the sheet passes through one or more nips between smooth rolls under high pressure, resulting in a smoother surface. Göttsching and Stürmer (1978c) observed significant effects of calendering on the quality of the fibers after they had been repulped and formed into new sheets of paper. The calendered fibers had a reduced tendency to swell with water during repulping. Soft-nip calendering, in which a steel roll is pressed against a cellulosecovered or polymer-covered roll, was found to be less damaging to strength characteristics after recycling of the fibers relative to hard calendering under conditions that provided comparable smoothness.

Sohn and Paik (2006) observed surprisingly large differences in the way hardwood vs. softwood kraft pulps responded to calendering. The calendered softwood fibers yielded a reduced strength of the recycled paper, whereas calendering actually had a positive effect in the case of hardwood fibers. These effects were over and above effects due to the drying and recycling; those processes tended to degrade the bonding ability of all of the fibers tested, including chemithermomechanical pulp (CTMP) fibers.

\section{Printing}

Effects of printing on the visible appearance of recycled paper, even after deinking, are so noticeable that it is easy to overlook the effect of the ink or toner on other attributes of the paper. Not all recycling of paper involves deinking. Many ink materials are quite hydrophobic, so they tend to decrease the surface energy of fibers to which they remain attached (Etzler et al. 1995). Kuys and Zhu (2004) observed that the presence of toner significantly increased the cationic demand of redispersed xerographic paper. Likewise, coatings used to enhance printing quality have an important effect on the cationic demand. Recycled stock from old magazine paper can be expected to have a much higher cationic demand than uncoated newsprint. Because the fiber compositions of the base sheet of the magazine paper was similar to that of newsprint, such results can be attributed to the negatively charged latex, phosphate dispersants, and clays found in the respective aqueous coating formulations.

\section{Converting}

The word "converting" can include a very wide range of procedures that are used to increase the value of a paper product in the eyes of a specific user. Converting processes can include cutting, laminating, folding, gluing, and creping, etc. In terms of the quality of recycled fiber furnish, many of these converting processes have the potential to increase the level of contaminants in recycled streams of cellulosic fiber. In some cases the difficulty of removing glue or laminated layers may render converted paper or paperboard products unattractive as a potential source of recycled fibers, even in cases where the fibers themselves may have relatively high potential value for use in paper. High levels of wax, wet-strength agents, release agents, adhesives, and exotic inks 
generally decrease the "recyclability" of waste paper (Webb 1992; Venditti et al. 2000; Watanabe and Mitsuhiro 2005). Another parallel issue of importance relates to the increased popularity of shredding documents and the extensive cutting of fibers that occurs during shredding.

\section{Storage and Use}

Aging

During the time that paper is stored, shipped, and used for various purposes there are opportunities for the fibers to undergo chemical as well as physical changes. As noted by Kato and Cameron (1999), it is reasonable to expect some embrittlement of high-temperature-aged paper due to increased cross-linking, which is usually attributed to hydrogen bond formation and increased crystallinity. But the high temperature conditions also are likely to accelerate chemical breakdown of cellulosic chains, an issue that will be considered in more detail later in this review. As noted by McComb and Williams (1981), the hydrolysis of cellulosic material is accelerated in the presence of acidity; for this reason, paper that has been produced under weakly alkaline conditions tends to "age" less compared with "acidic" papers (Hubbe 2005a).

Effects of acidic vapors were demonstrated persuasively in an unplanned experiment that occurred in one of the authors' laboratories. A stack of pressuresensitive labels had been left in a top shelf of a cabinet that also contained bottles of reagent-grade acid solutions. After two years of such storage, the labels themselves, as well as the release paper backings, had become very brittle. Similar labels, kept in another cabinet, were not brittle.

\section{Age distribution}

While on the subject of aging, it has been noted that a piece of recycled paper is likely to contain fibers having a wide range of age. The different fibers making up a paper sample are likely to have been subject to different number of (recycling) cycles. Cullinan (1992) and Gerspach et al. (1993) developed models to estimate the likely distributions in age of fiber in recycled paper products. To be useful, such models require sound data concerning wastepaper collection. Related work led Phipps (1994) to conclude that large amounts of recycled fiber can be incorporated into newsprint furnish without major loss in physical properties.

Cildir and Howarth (1972) carried out a study in which the fraction of recycled fibers that were incorporated into each successive generation of handsheets was carefully varied, up to a maximum proportion of three-quarters. They defined a parameter called the "recycle factor." Its value was found to be critical; paper quality was not greatly affected by recycling until the value of "recycle factor" approached the upper end of the range studied.

As a caution against overestimating effects of multiple recycling sequences on fiber strength characteristics, Nazhad (2005) noted that, in many cases, kraft fibers tend to reach a plateau of physical characteristics after about five cycles of drying and repulping. Such effects even can be viewed as beneficial, to the extent that repeatedlyrecycled fibers might be expected to have a more consistent quality. Issues related to 
increased dimensional stability and ease of drying of kraft fibers that have been dried at least once will be considered at the end of this article.

\section{Recycling}

After various types of wastepaper are collected and sent to a paper recycling mill, there are many possible unit operations. Many of them are optional. The most basic is to redisperse the fibers in water, i.e. "repulping." Despite the large shear and energy used in repulping equipment, most researchers agree that there is little damage to individual fibers as a result of the initial repulping. The forming of damp fibers into sheets, in the absence of drying, has relatively little effect on fibers' characteristics. By contrast, as will be described in the next two subsections, significant changes in the suitability of recovered fibers for making recycled paper can be expected when the pulp is subjected to further refining. In some respects, neither de-inking nor further refining is absolutely required in order to make recycled paper. On the other hand, product requirements in terms of appearance and strength are likely to render both de-inking and further refining absolutely essential in many cases.

\section{Deinking}

The subject of deinking is complex and multifaceted (Ferguson 1992b; Göttsching and Pakarinen 2000; Rojas 2004). In terms of fiber quality, deinking operations mainly affect the degree to which the fibers are contaminated with non-cellulosic materials. The types of contaminants that are often encountered in the paper machine systems of paper recycling mills recently have been reviewed (Hubbe et al. 2006). On the one hand, an effective de-inking program is expected to reduce the levels of inks, stickies, and dirt, etc. But on the other hand, it can be expected that some of the chemicals used in the deinking process will remain with the recovered fiber. The latter chemicals may include fatty acids (and especially, the calcium salts of fatty acids), nonionic surfactants, dispersants, and, in the case of mechanical pulps, often the byproducts of bleaching with hydrogen peroxide (Haynes and Röring 1998). Peroxide bleaching is known to increase the cationic demand of the bleached mechanical pulp to relatively high levels due to release of carboxylated hemicellulose species and breakdown products. On the other hand, deinking operations do not appear to significantly damage the fibers themselves, and deinked fibers tend to be rather "clean" with respect to the presence of wood resins (Webb 1992; Klungness 1993; Alanko et al. 1995).

\section{Re-refining}

As will become clear from later discussion, recycled kraft or sulfite fibers, when dispersed in water, and even when subjected to deinking, can have a reduced bonding tendency in comparison to their condition just before they were originally made into paper. Papermakers often strive to make up for this deficiency by judicious application of compression and shearing forces in a refiner. The word "judicious" should be stressed for two reasons. First, it can be expected that most of the recovered fibers already have been refined. Second, harsh refining of recovered fibers can be expected to produce a lot of fines. Though it is reasonable to expect that drying of kraft fibers would render the 
pulp more susceptible to creation of fines when redispersed in water and subjected to additional refining, this expectation does not appear to have been definitively proven.

A high level of fines tends to slow down the dewatering of the wet web of paper (Hubbe and Heitmann 2007) and the associated loss of fiber length is likely to decrease other strength attributes of the paper product, such as tear strength and folding endurance. Strategies for optimal refining of recycled fibers will be discussed later, when considering ways to overcome various adverse effects of recycling on fiber attributes.

\section{PHYSICAL EFFECTS OF DRYING, STORAGE, AND USE}

The conditions to which fibers are exposed during paper production, converting, storage, use, and recycling can induce various different changes in fiber morphology, surface characteristics, and suitability for use in the formation of recycled paper. Such changes can be described in various ways, using terms such as hornification (i.e. loss of ability of the fibers to swell with water), semi-irreversible closure of nano-sized pore spaces, decrease of the external surface area, decreases in flexibility and conformability, breakage or other damage to the fibers, and a number of other such changes. A note of warning is appropriate, though. As mentioned by Garg and Singh (2006), even if one is successful in describing all of the significant changes that occur when a given set of fibers is made into paper, used, and recycled, it may remain unclear which of the factors have the major influence on the product attributes.

\section{Hornification}

Although all researchers don't agree concerning a definition of "hornification," most users of the word imply both a reduction in the amount of water that fibers hold within their cell walls, and also a tendency for rewetted fibers to be stiffer and less conformable than before being subjected to drying or other kinds of stresses (Jayme 1944; Stone and Scallan 1966; Szwarcsztajn and Przybysz 1976, 1978; De Ruvo and Htun 1983; Mansito et al. 1992; Laivins and Scallan 1993; Minor 1994; Nazhad and Paszner 1994; Scallan 1998; Weise 1998; Weise and Paulapuro 1999; Diniz et al. 2004; Welf et al. 2005; Billosta et al. 2006). "Hornification" also can be used when cellulosic fibers are subjected to other kinds of stresses, including heating without drying (Lyne and Gallay 1950; Roffael and Schaller 1971; Welf et al. 2005), as long as there is a simultaneous loss of water-holding ability and strength potential.

Figure 1 illustrates a general concept that can be used to explain changes in the water-holding ability of kraft fiber cell walls. According to this concept the process of refining tends to open up submicroscopic spaces within the lamellar structure of the fiber cell walls. Evidence of internal fibrillation during refining includes swelling in the thickness direction of fibers (Jayme 1944; Jayme and Büttel 1968), and also an increase in wet fiber flexibility (Paavilainen 1993). As will be described, spaces created in the fiber cell wall tend to close in a semi-irreversible manner when the fibers are dried. 

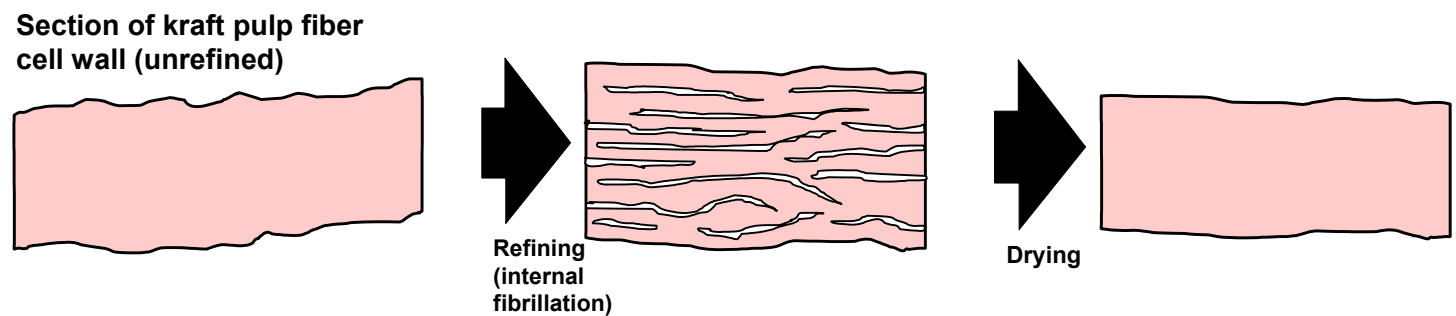

Figure 1. Schematic illustration of the swelling of kraft fiber cell walls during refining, followed by semi-permanent closure of inter-lamellar pore spaces when the fibers are dried

\section{Water retention value tests}

The most commonly used method to assess the swelling ability of cellulosic fibers has been the so-called water retention value (WRV) test (Jayme 1944; Anon. 1981, 2000). It even has been proposed that WRV results be used as the defining criterion of whether or not hornification has occurred in a given case (Weise 1998). To carry out a WRV test, a wet sample of fibers is inserted into a specially prepared centrifuge tube. The wet fibers rest on a filter surface, and there is space below to accommodate any water that is removed from the fibers. Most researchers, starting with Jayme (1944), who developed the method, have assumed that centrifugation mainly removes water from the spaces between adjacent fibers, as well as from fiber lumens, and that the water remaining after fibers is located within the cell walls. Recently, however, it has become clear that a substantial portion of the water remaining after centrifugation may be associated with fibrils at the outer surfaces of fibers. The importance of externally held water to the results of WRV tests is supported by the fact that high-mass cationic polymers, which are far too large to affect water held within the cell walls of fibers, can significantly decrease WRV results (Ström and Kunnas 1991). Thus, it can be said that WRV tests give a measure of "overall" water retention, including both water in the cell wall and also water associated with fiber surfaces.

Results of WRV tests have shown that the most dramatic losses in water-holding ability of relatively low-yield fibers take place in the case of well refined fibers (De Ruvo and Htun 1983). These authors reported that most of the gain in WRV that had been achieved upon refining of the fibers was lost even under very gentle drying conditions. More recently, it has been shown that losses in WRV tend to occur in two stages, an initial loss due to drying itself, regardless of temperature, and then a further loss when the temperature of drying exceeds about $150{ }^{\circ} \mathrm{C}$ (Hubbe et al. 2003b; Welf et al. 2005). A remarkable parallel was found between such WRV results and the results of strength tests. The reason that both sets of results showed losses due to drying itself, regardless of temperature, was attributed to pore closure. Pore closure can be expected to cause fibers to be stiffer for the same reason that a stick is much stiffer than a rope of equal size and density; stiffness depends on the degree to which the fibrous components of a structure are bonded together, preventing them from sliding past each other. The fact that both WRV and paper strength experienced further losses when kraft fibers were exposed to relatively high temperatures during drying was attributed to further shrinkage, possibly due to plastic flow. Related work by Weise et al. (1996) showed that most of the loss in WRV occurred as the solids content of unbeaten bleached kraft fibers was increased in 
the range 20 to $75 \%$, which corresponds to the removal of free water. Further loss of water due to evaporative drying caused further shrinkage, but only a relatively small additional loss of WRV when the fibers were subsequently placed back in water.

\section{Fiber saturation point tests}

The term "fiber saturation point" (FSP) has become associated with a reputedly more reliable, but also more painstaking method of evaluating the amount of water held within fiber cell walls. An FSP test involves mixing a relatively high consistency fiber slurry with a solution of high molecular mass dextran (Scallan and Carles 1972; Scallan 1977). The dry mass of fibers, the total amount of water, and the total amount of dextran need to be precisely known. After a period of mixing, a filtrate sample is obtained, and the dextran concentration is determined e.g. by interferometry (Stone and Scallan 1968). The validity of this test relies upon the assumptions that the dextran has no affinity for the fiber surfaces and that its molecular size does not allow it to pass into the spaces within a cell wall.

Recently, fiber hornification was evaluated by a parameter termed 'hard-toremove (HR) water content,' which was defined as the ratio of water mass to fiber mass at the transition between the constant rate zone and the falling rate zone from the isothermal thermogravimetric analysis (TGA) experiments (Park, et al. 2006b). The results indicated that the HR water content could be used as a measurement technique for fiber hornification, showing a close correlation with the WRV over repeated drying and wetting cycles. As expected, fully bleached kraft pulped fibers demonstrated a much larger decrease in the HR water content upon experiencing multiple drying and wetting cycles than did mechanically pulped fibers. Further, refined fibers experienced increased hornification over multiple drying and wetting cycles relative to unrefined fibers.

\section{Factors that influence the extent of hornification}

An important clue about the nature of hornification is provided by the fact that high-yield pulps, such as thermomechanical pulp (TMP), appear to be much less susceptible to changes when they are dried (Bovin et al. 1973; Ferguson 1992a, 1994; Houen et al. 1993; Rossi et al. 1994; Phipps 1994; Alanko et al. 1995; Chakravarthi et al. 1995; Gavazzo et al. 1995; Law et al. 1995; Göttsching 1995; Putz 1996; Ackermann et al. 2000; Qian et al. 2005; Law et al. 2006; Park et al 2006b). Göttsching and Stürmer (1978b) observed contrasting results in the case of stone groundwood pulps, which appeared to lose a significant amount of swelling ability upon drying. Lyne and Gallay (1950) found that bleached sulfite pulps were more susceptible to losses of swelling ability upon drying, in comparison to unbleached sulfite. In addition, relatively low-yield pulps do not appear nearly as prone to hornification effects until they have been refined (Stürmer and Göttsching 1979). Bayer (1996) compared a variety of different mechanical and chemi-mechanical pulps, both hardwood and softwood, with kraft fibers, and found a wide range of hornification behaviors. Billosta et al. (2006) proposed that such differences between different types of pulps can be explained in terms of their differing morphology on a sub-microscopic scale. The opening up of inter-lamellar spaces within fiber cell walls by either removal of lignin or by refining appears to make them more susceptible to subsequent changes when the fibers are dried. Jang et al. (1995) noted that 
mechanical pulp fibers appear to flatten as a net result of papermaking, use, and recycling, an effect that can yield denser, stronger recycled paper in comparison to the first time that the fibers were used. Law (1996) observed significant decreases in water retention when mechanical pulp fibers were dried and recycled, but, unlike kraft pulps, such loss of swelling ability was accompanied by increases, rather than decreases in the strength of the recycled paper.

\section{Pore Closure and Failure to Re-open}

Many researchers have concluded that the loss of swelling ability of low-yield cellulosic fiber upon drying is due to the closure of pore spaces in the cell walls, plus the inability of many of the pores to reopen if the fibers are rewetted (Stone and Scallan 1966; De Ruvo and Htun 1983). To support such a hypothesis, it is necessary to quantify not only the total volume of pores within fibers, but also the distribution of pore sizes.

\section{Solute exclusion with probe molecules of different sizes}

Aggrebrant and Samuelson (1964) were apparently the first to use the solute exclusion method for the study of cellulose fibers, mixing fibers with a known concentration of non-adsorbing polymer solution, and then measuring the concentration of free solution in the bulk. In cases where the polymer has a very high molecular mass, this is basically the same as the FSP test, as just described. Stone and Scallan (1966) were able to obtain considerably more information by carrying out such tests by using a series of dextrans molecules having widely different, but narrowly defined molecular mass. The ability of the polymers to penetrate into the fibers was found to be a strong function of molecular mass, consistent with the idea that the effective size of the molecule in solution corresponds to the minimum size of pore spaces that it can enter. By use of these tests Stone and Scallan (1966) were able to show substantial irreversible pore closure, due to drying. The pores that failed to reopen after rewetting corresponded to those that were just large enough to accommodate probe molecules having solution dimensions in the range of about 2 to $20 \mathrm{~nm}$. Because of an effect called "excluded volume," it can be expected that the physical dimensions of the pore spaces measured in this way may be about two times larger than the physical diameters of the probe molecules (Alince and van de Ven 1997). Related work, in agreement with the main conclusions, has been reported by others (Yamagishi and Oye 1981).

\section{NMR studies of pore size distribution changes}

Because NMR tests can distinguish between water molecules adjacent to surfaces vs. those in the bulk, researchers have used NMR analysis to obtain information about pore size distributions in cellulosic materials (Maloney et al. 1997; Haggkvist et al 1998). Based on results of such research Haggkvist et al. (1998) concluded that shrinkage of pores as a result of drying was similar to what happens when wet fibers are pressed to remove water. Due to differing spin-lattice relaxation profiles of the protons, depending on the method of water removal, it could be concluded that the sizes of typical pores decreased gradually as more and more water was removed. Maloney et al. (1997) concluded, based on NMR results, that pressing had a disproportionate effect in closure of the larger pores that were present in fibers. 


\section{Microcalorimetry for analysis of pores within fibers}

Yet further information about pores within cellulosic fibers has been revealed by differential scanning calorimetry (DSC) studies (Maloney et al. 1998a,b; Park et al. 2006a,b,c). Such studies are based on the principle that the freezing characteristics of water can depend on how close the water molecules are to various surfaces. Maloney et al. (1998) identified three types of water associated with cellulosic fibers, bulk water, freezing bound water, and nonfreezing bound water. The freezing temperature of the freezing bound water was depressed, relative to that of bulk water, and the authors used the freezing point depression as evidence that such molecules are in a region of reduced structure, compared to bulk water, and that the more disorganized layer of water always extends to the same distance out from a wetted surface. It is reasonable to assume that the non-freezing water identified in such experiments consists of "water of hydration," i.e. molecules of water that are directly interacting with the cellulose. Park et al. (2006a), using similar methods, concluded that the larger pores within kraft fiber cell walls were the earliest to close during drying, followed by smaller pores.

One way in which to simplify interpretation of the DSC data from experiments of this type is to replace water, as the suspending medium, with a non-aqueous liquid. Wang et al. (2003) used this approach with cyclohexane. After making some allowance for a de-swelling effect of the liquid, results were in general agreement with water-based DSC tests of the pore size distribution.

While questions remain about the fundamental reasons behind the three types of water, it has been possible to conclude from such studies that bulk water ceases to exist within fibers if they are pressed and dried to solids levels between $47 \%$ and $67 \%$ (Maloney et al. 1998). At this point the capillaries in the fiber have collapsed, and the hemicellulose begins to dehydrate. After further drying to $78-81 \%$ solids, the fine pores are completely collapsed, and only non-freezing bound water remains.

\section{Surface Area}

Another approach to characterizing changes that occur upon drying, using, and recycling paper involves various measurements of surface area. Results of such measurements are likely to be affected by the extent of fibrillation at fiber surfaces, whether or not the fibrils have become matted down to the surface as a result of their history of treatment (Ackermann et al. 2000), and whether the method employed is able to detect internal "surfaces" associated with sufficiently large pores in the cell walls. Using a nitrogen adsorption technique, following a solvent-replacement-drying method, Stone and Scallan (1966) observed significant decreases in the surface areas of sulfite pulp in cases where the water content was reduced to $42 \%$ or below. Once the fibers had been completely dried, the surface area had decreased to about $1 \%$ of its initial value.

\section{Polyelectrolyte adsorption as a surface area assay}

The reason that cationic polyelectrolytes can be used to evaluate the surface areas of cellulosic materials is that they tend to adsorb with high affinity onto negatively charged substrates. The cationic polyelectrolytes' charged nature also guarantees that no more than a single layer of molecules will be formed. One can safely assume that 
positively charged polyelectrolytes of suitably high molecular mass will continue to adsorb onto the surfaces of interest from an aqueous solution until no uncovered areas remain. Although many different factors can affect the molecular conformations, and therefore the density of adsorbed polyelectrolyte molecules (Wågberg and Ödberg 1989), it is reasonable to assume that adsorption is proportional to the area of accessible surfaces.

Gruber et al. (1996) used polyelectrolyte adsorption to study the effects of drying and recycling sulfite fibers. In the case of poly-DADMAC molecules larger than about $50,000 \mathrm{~g} / \mathrm{mole}$ there was only a moderate decrease in the adsorbed amount when the fibers were dried and recycled, compared to their initial condition. However, there was a marked decrease in the adsorbed amount of a lower-mass poly-DADMAC, having a mean molecular mass of $14,000 \mathrm{~g} /$ mole. These observations were taken as evidence that pores roughly within the size range between that of the $14,000 \mathrm{~g} /$ mole molecules and the $50,000 \mathrm{~g} / \mathrm{mole}$ molecules existed in the never-dried sulfite samples, but at least some such pores closed irreversibly during drying and recycling. Similar effects were reported by Hubbe et al. (2003), for unbleached kraft fibers, and by Lee and Joo (2000) in the case of bleached kraft fibers. Thode et al. (1955) used similar principles, but with a strongly adsorbing dye, to show reductions of surface area of sulfite pulps due to drying.

\section{Enzyme reactivity as a measure of surface area}

Because enzymes consist of large, multiply-folded protein molecules, it is reasonable to expect them to be excluded from pores in the cell walls of cellulosic fibers, depending on the pore size. Though it would make sense that rates of hydrolysis by cellulases can depend on many different factors, such as the extent of crystallization of the cellulosic material, it is still possible to use the overall rate of hydrolysis as a rough measure of surface area. This approach requires the use of an excess addition of the enzyme, such that surface area becomes a limiting factor. As described by Pycraft and Howarth (1980a), the extent of hydrolysis can be followed by sugar analysis. Further work by the same authors (1980b) revealed a strong correlation between the initial rates of enzyme hydrolysis and the strength of paper that had been subjected to a range of conditions during drying or pressing. Drying decreased the hydrolysis rates significantly, and the effects became increasingly larger with increasing severity of drying conditions on a pilot paper machine.

Related work was carried out by Fan et al (1980), but they interpreted their results not in terms of surface area, but in terms of degree of crystallinity. In fact, one could argue that either a decrease in accessible surface area or the presence of more difficult-tohydrolyze crystalline material at the surfaces both might be able to explain the same observations.

\section{Flexibility, Relative Bonded Area (RBA), and Sheet Density}

Flexibility of Fibers in the Wet State

Various researchers have reported strong correlations between the flexibility of wet fibers and the strength of paper formed by such fibers (Tam Doo and Kerekes 1982; Steadman and Luner 1985; Pavilainen 1993). It is reasonable to expect that more flexible fibers should better conform to the shape of adjacent fibers, developing a higher 
proportion of bonded area. Scallan and Tigerström (1991) and Dulemba et al. (1999) found that the elastic modulus of wet kraft fibers was sometimes doubled due to the effects of drying and recycling. The effect is illustrated in Fig. 2. In the case of sparingly refined, moderately high-yield unbleached kraft pulp the method of Steadman and Luner (1985) was used to show significant decreases in fiber flexibility due to drying (Zhang et al. 2004; Hubbe and Zhang 2005). After a moderate degree of refining of the redispersed fibers it was still possible to detect a deficit in flexibility. However, the additional refining increased the water retention value back near to its original value, and the strength of the paper also could be recovered by subsequently refining the once-dried fibers to the same degree as a control sample (e.g. 6000 revs. of a PFI refiner).
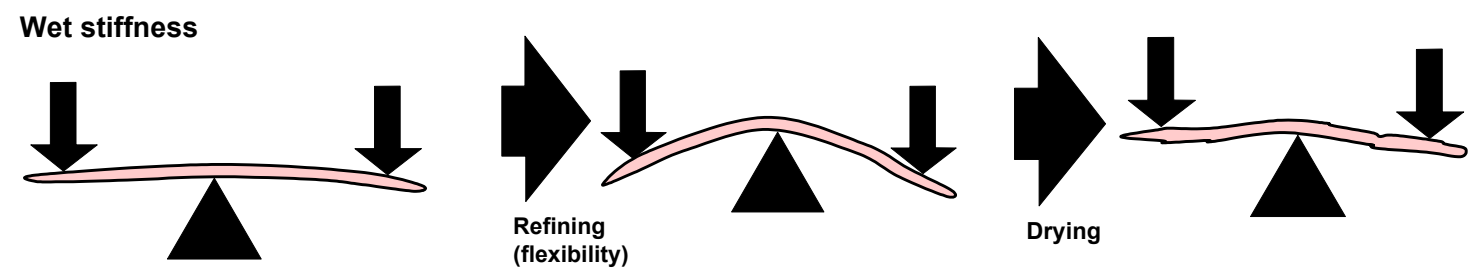

Figure 2. Kraft fiber wet-flexibility typically increases due to refining, but the fibers become stiff when they are dried and rewetted, as in the case of papermaking, followed by recycling.

Cao et al. (1999) concluded that wet-flexibility was a major factor in determining the bonding potential of fibers from red cedar. Their study compared thermomechanical pulps (TMP) to fibers having various degrees of hemicellulose removal. Based on the apparent densities, these authors concluded that the once-dried fibers were less conformable, and that this factor was responsible for the reduced strength of paper that was made from them. Somwang et al. (2001) reached similar conclusions regarding bleached kraft pulps, comparing never-dried and dried samples; bonded areas were compared by confocal laser scanning microscopy.

\section{Relative Bonded Area}

One of the most elegant ways to quantify the ability of fibers to conform to the surface morphology of adjacent fibers is based on the ability of a resulting sheet of paper to scatter light. To a first approximation it has been found that the tendency of paper material to scatter light, i.e. the " $s$ " coefficient of Kubelka-Munk analysis (Page 1969; Scott et al. 1995), is directly proportional to the exposed surface area of the fibers. The analysis effectively ignores any features, including pores that are smaller than about 100 $\mathrm{nm}$ in size, since such features are too small to be effective in scattering visible light. A quantity called the relative bonded area $(R B A)$ is defined as follows,

$$
R B A=100 \% \times\left(s_{\text {unbonded }}-s_{\text {test }}\right) / s_{\text {unbonded }}
$$

where $s_{\text {test }}$ is the light scattering coefficient of the paper sheet under consideration, and $s_{\text {unbonded }}$ is the light scattering coefficient of a sheet having the same composition, but which has been prepared from a non-swelling solvent, such as butanol. The latter kind of 
"paper," tends to be very bulky, very opaque, and extremely weak. The $s_{\text {unbonded }}$ parameter also can be determined by extrapolating to zero strength from the plot of scattering coefficient versus tension strength (Page 1969).

Gurnagul and Page (2001) carried out an analysis, using the $R B A$ criteria, to determine the cause of loss in bond strength of kraft sheets due to recycling. The results showed little change in $R B A$, leading the authors to conclude that the main effects of drying and recycling involved a loss in the shear bond strength per unit of bonded area. In other words, there was a lower strength at near-equal optical properties of the paper. These findings were in reasonable agreement with those of McKee (1971) and Nazhad (2005), but contrary to those of Ellis and Sedlachek (1993) as well as those of Cao et al. (1999).

\section{Bulk and apparent density of the paper}

A less quantitative, but highly practical means of judging the wet-conformability of papermaking fibers is to compare the apparent density values of uncalendered sheets prepared under constant conditions of wet-pressing. Various authors have cited evidence of this type to support their conclusions that dried and recycled fibers were less conformable than they had been just before the formation of the initial paper (Göttsching and Stürmer 1978b; Guest and Weston 1990; Somwang et al. 2001; Hubbe et al. 2003). Fahmy and Mobarak (1971) showed that the drying of biological cellulose increased its density to the point that the calculated amount of extra space in the material became essentially zero.

\section{Re-Adhesion of Fibrils and Fines to Fiber Surfaces}

The next subject to consider is an effect due to air-water interfaces, i.e. capillary forces. The enormous strength of such forces was described by Campbell $(1947,1959)$, who was among the first to suggest that capillary forces played a key roll in the development of paper's dry strength. The process of drawing the cellulosic surfaces close together, just as water is being evaporated from between the fibers, appears to facilitate the formation of hydrogen bonds (Hubbe 2006b).

Evidence suggests that capillary forces also play a role in the matting down of fibrils, as well as fiber fines, on fiber surfaces during evaporation of water from paper. The effect is illustrated in Fig. 3. Klofta and Miller (1993) described such effects with bleached kraft fibers.
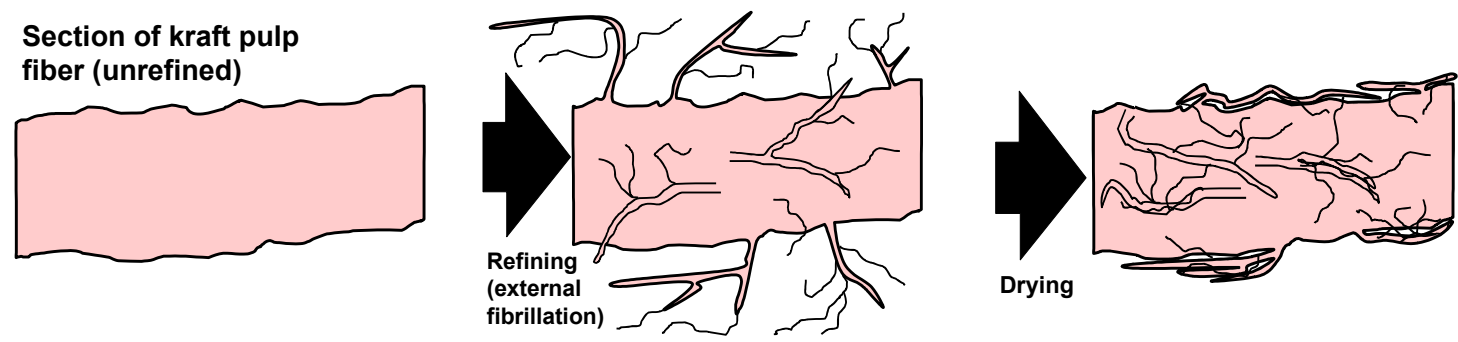

Figure 3. Schematic illustration of external fibrillation of a kraft fiber due to refining and the tendency of fibrils to become tightly matted down on fiber surfaces as a result of drying 


\section{Fiber Length}

If you ask a stranger what causes recycled paper often to be weaker than paper made from freshly prepared fibers, one often gets the answer that, "probably it's because the fibers are shorter due to breakage." This conventional wisdom, though often true, is often overstated. Ellis and Sedlachek (1993) listed "fiber length" among four key factors that possibly can account for changes in the strength of paper made from recycled fibers. They identified the quantity of $\mathrm{C} / \mathrm{PL}$ ( $\mathrm{C}$ is coarseness, $\mathrm{P}$ is fiber perimeter and $\mathrm{L}$ is fiber length, weight average) in a model of the tensile strength of paper. This quantity did not change much during repeated drying and wetting cycles (no repeated refining) in a laboratory setting. According to Ackermann et al. (2000), the effects of changes in fiber length usually are negligible relative to other factors.

The fuller truth about "fiber length" requires that one consider at least three key effects. The first is the extent to which fine matter may be lost when fibers are recycled. Especially in cases where recovered fibers are subjected to deinking treatments, substantial amounts of fiber fines and fillers can be expected to end up as part of the sludge obtained from coagulation of wastewater coming from the process (Göttsching and Pakarinen 2000). Second, additional fine matter can be generated when the fibers are refined, for an additional time, in an attempt to achieve the needed inter-fiber bonding, depending on the specifications of the paper product. And third, it is reasonable to expect that refining of recycled kraft fibers, depending on its intensity (Paulapuro 2000), may exert forces within occasional fibers that exceed their tensile strength. A higher proportion of fine matter automatically lowers the average fiber length. Moreover, it has been suggested that the brittle nature of recycled fibers renders them more susceptible to breakage during refining (de Ruvo and Htun 1983).

\section{Fiber Cross-Sectional Shape}

Recycled fibers also tend to differ in shape, in comparison to the first time that they were prepared for papermaking.

\section{Kraft fiber effects}

Weise and Paulapuro (1996) observed changes in kraft fibers by means of confocal laser microscopy. The relatively early stages of drying, up to about $70 \%$ solids, caused uneven shrinkage, and the fibers became visibly wrinkled. The effect is illustrated in Fig. 4. The authors pointed out that such change occurred within the same range of moisture loss associated with hornification, i.e. the irreversible losses of water retention and inter-fiber bonding ability. Further drying to higher solids levels, merely caused isotropic shrinkage, without causing additional changes in the cross-sectional shape of the fibers.

\section{Flattening of mechanical fibers}

In the case of mechanical fibers, various authors have reported a tendency for flattening, associated with a more collapsed lumen, after recycling (Ackermann et al. 2000; Houen et al. 2003; Jang et al. 1995). It has been suggested that such flattening is why recycled mechanical fibers sometimes yield denser and stronger paper than they did during the first cycle of papermaking (Ferguson 1992a, 1994; Houen et al. 2003; Jang et 
al. 1995; Ackermann et al. 2000). However, compared to the effects of recycling on chemical pulps, the effects for mechanical pulps tend to be rather subtle (Bovin et al. 1973; Ferguson 1992a, 1994; Howard and Bichard 1992).
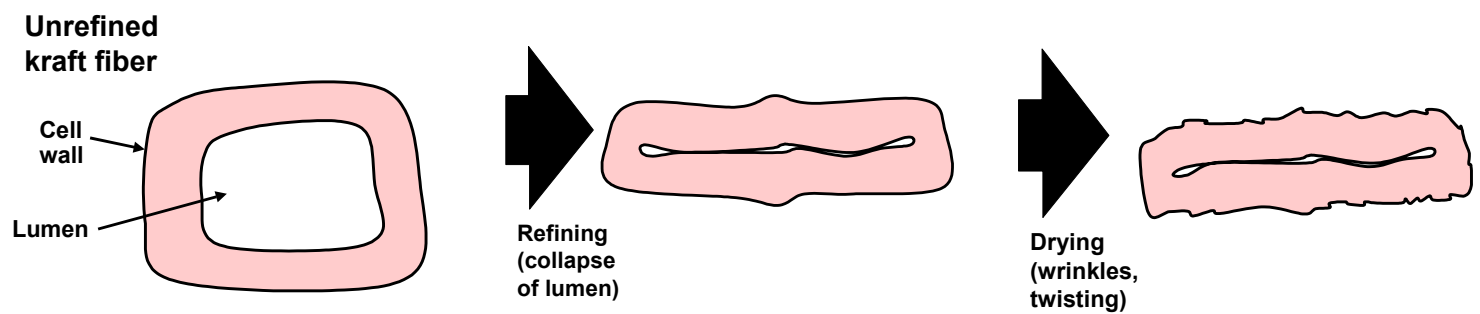

Fig. 4. Expected changes in cross-sectional shape of kraft fibers due to refining followed by drying

\section{Microcompressions}

Because of the mostly lengthwise orientation of cellulose polymer chains, as well as fibrillar elements within the predominant S2 layer of fibers in most woody plants, it follows that individual fibers will be quite dimensionally stable in their length-wise dimension, even when subjected to large changes in moisture content. The fact that kraft fibers can shrink by up to $20-30 \%$ in the transverse and radial thickness dimensions (Page and Tydeman 1962), when dried, can be attributed to such factors as amorphous (noncrystalline) regions in the cellulosic polymer structure, the existence of inter-lamellar pore spaces (Stone and Scallan 1968), and the further internal delamination of fibers when they are refined. But something interesting happens when two fibers, at right angles to each other, are dried while in contact with each other. The two surfaces can appear to hold onto each other with such tenacity that shrinkage of one fiber in its radial or transverse direction causes the adjacent fiber to undergo microcompressions, becoming wrinkled and shorter than it was before (Page et al. 1986). The effects of microcosmpression can be so prominent that a "skirt" is visible at the edges of the contact region even after the fibers have been separated from each other (Page and Tydeman 1962; Clark 1985; Nanko and Ohsawa 1989).

\section{Restrained drying}

In what appears to be a closely related phenomenon, substantial differences in the strength potential of dried and redispersed fibers have been found, depending on whether the fibers were dried under restraint, as part of a sheet of paper formed under tension (Gurnagul 1995). For example, Mocchiutti et al. (2006) found that the strength of paper formed from unbleached kraft fibers fell to a greater extent if they were dried without restraint, compared to when the sheets were held at a constant dimension during drying.

\section{Delamination, Fragmentation, and other Damage}

In addition to the other physical changes mentioned above, recycled fibers show effects that might be called "damage." For instance, recycled fibers tend to show a higher frequency of micro-indentations (Nazhad and Paszner 1994). The term microindentation refers to features that, though small, can adversely affect properties such as 
compression strength and dimensional stability of paper (Hartler 1995). Kraft fibers subjected to repeated papermaking, drying, and relatively gentle repulping in water were found to become increasingly delaminated (Okayama 2002). Cracks were observed, and physical strength attributes of the recycled sheets were reduced.

\section{CHEMICAL EFFECTS OF DRYING, STORAGE, AND USE}

Physical changes, as summarized in the previous section, account for only part of what happens to fibers when they are made into paper, dried, subjected to various conditions of use, and then recycled. Chemical changes can be equally important.

\section{Chemical Aspects of Pore Closure and Bonding}

From a chemical standpoint, one of the most interesting questions to consider is why the closed pores in the cell walls of fibers don't simply imbibe water and re-open when dried kraft fibers are placed back into water. The facile answer is that hydrogen bonds form between adjacent cellulosic surfaces (including all components, such as hemicellulose and lignin) when they are dried in contact with each other. Many scientists have mentioned "hydrogen bonding" as being mainly responsible for preventing reopening of pores when dried chemically pulped fibers are rewetted (Higgins and McKenzie 1963; Laivins and Scallan 1993; Scallan 1998; Kato and Cameron 1999). But hydrogen bonds ordinarily would be expected to be highly reversible. For instance, the bonding between two fibers in paper is easily disturbed upon slushing paper in water, and the fibers are readily released from one another. Thus, one needs to ask why hydrogen bonds joining cellulosic surfaces within fiber walls don't just become replaced by hydrogen bonds involving water molecules.

It can be speculated that the hydrogen bonding between fibers is reversible because the original two surfaces have independent surface topography with random imperfections; hence they do not "fit together" effectively when dried. Thus, the bonds are less permanent with respect to re-wetting. In contrast, for a pore in the cell wall that is created by separating two adjoining lamella, the two sides of the formed "pore" would have perfectly meshing topologies as they were formed from the same rupture area. Thus, when these two surfaces are re-joined by drying, the topologies will mesh almost perfectly, providing a more intimate, permanent bond. Although this argument is plausible, no evidence of this is known. Chemical changes of surfaces that are exposed by refining, e.g. depolymerization or oxidation, would be expected to render such healing more difficult.

\section{Crystallization as a "locking" mechanism}

Lundberg and de Ruvo (1978a) proposed that there must be some kind of locking mechanism when pores within cellulosic fibers close due to drying. These authors proposed that such closure "erases the memory" that a pore existed. In effect, the solid phase becomes continuous across where there used to be a gap in the cellulosic structure. It is well known that cellulose owes its insoluble nature to the existence of crystalline domains (Attala 1977). Within these domains the hydrogen bonds are arranged in a 
regular pattern, including both intra- and inter-molecular chain hydrogen bonding. It has been proposed that the local formation of semi-crystalline domains at the facing surfaces of closed pores within fibers can account for the inability of such pores to re-open (Kulshreshtha et al. 1977; Weise 1998; Ackermann et al. 2000). The mechanism is illustrated in Fig. 5. Newman and Hemmingson (1997) proposed, in addition, that when adjacent crystalline regions of cellulose are dried in contact, they essentially can be healed together and become one.
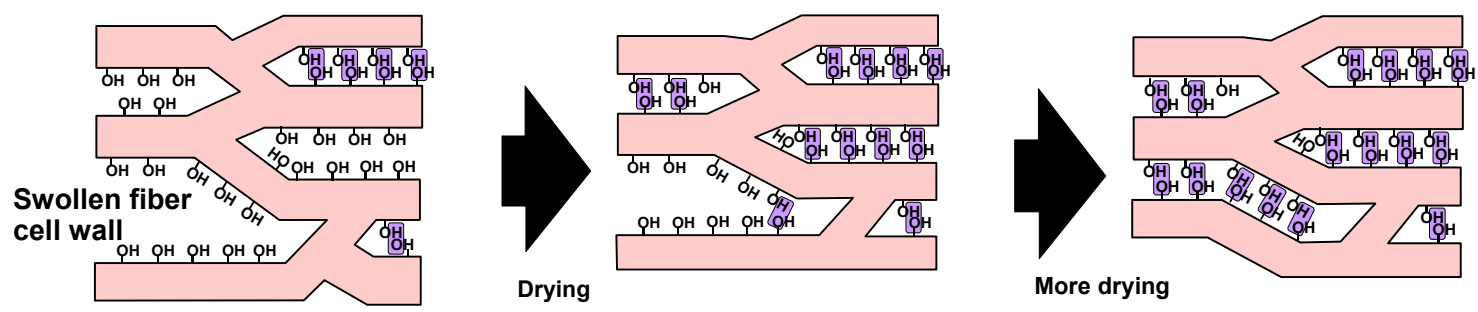

Figure 5. Schematic diagram of mechanism by which the "zipping" shut of pores is mediated by highly orderly hydrogen bonds, resulting in crystalline micro-domains that resist separation. Interfibril hydrogen bonds are shown with shading.

Support for the idea that localized crystallite formation may prevent re-opening of pores makes sense in terms of cellulose's very high tendency to crystallize, especially in the presence of heat and moisture. Amorphous cellulose can be produced only by special treatments, such as extensive ball-milling in the absence of moisture (Hatakeyama and Hatakeyama 1981). The same authors showed, by means of differential scanning calorimetry (DSC), X-ray diffraction, and density gradient tests, that amorphous cellulose was rapidly converted back to a partly crystalline state when it was exposed to moisture (see also Wadehra and Manley 1965). Atalla (1977) showed that the level of crystallization within cellulosic material can be increased by such conditions as heating the aqueous suspensions under pressures corresponding to a typical kraft pulping operation. Likewise Kimura et al. (1974) concluded, based on DSC tests, that heating in the wet state can increase the proportion of crystalline regions within amorphous cellulose. Water appears to plasticize cellulose, facilitating easier transformation to a crystalline phase; this assertion is further supported by work showing that steam-drying tends to hurt bonding properties of fibers to a greater degree, in comparison to oven drying (Guest and Voss 1983). Heating to yet higher temperatures can have different effects, however. Hattula (1986) found that heating under pressure in distilled water increased the crystallization of cellulose in TMP fibers over the range 130 to $170{ }^{\circ} \mathrm{C}$, but crystallinity decreased with further heating in the range 175 to $200{ }^{\circ} \mathrm{C}$.

It has been difficult to obtain direct evidence of changes in crystallization that might explain various effects associated with drying for fibers. Somwang et al. (2002) used X-ray diffraction methods and detected slight increases in crystallinity as a result of recycling of handsheets. The increased crystallinity was attributed to decreases in the proportion of amorphous (non-crystalline) cellulose. The relative changes were too small, however, to be detectable by Raman spectroscopy. More distinct evidence of increased crystallinity has been obtained based on changes in the displacement density of 
bacterial cellulose, comparing dried vs. undried samples (Fahmy and Mobarak 1971). Further evidence of persistent, crystal-like hydrogen bonding has been obtained by deuterium exchange rate studies (Sumi et al. 1963). Drying reduced the proportion of deuterium-exchangeable groups, as would be expected if the relative amount of crystalline cellulose increases. In the case of cotton, Iyer et al. (1991) observed a much greater increase in crystallinity resulting from slow drying in humid environments, in comparison with dry heating. The most favorable conditions of moist drying increased the level of crystallinity by ten to fifteen percentage points. Yamagishi and Oye (1981) likewise found increases in crystallinity due to recycling. Back et al. (1967) observed a sharp drop in dry tensile strength when samples of paper were heated above $200{ }^{\circ} \mathrm{C}$; they concluded that his effect was due to thermal softening, leading to a hardening of the fiber surfaces.

To make matters even more complicated, work by Atalla et al. (1984) showed that high temperature treatment of cellulose in the presence of moisture is able to convert cellulose into various different crystalline forms. These forms, which have been given titles such as "cellulose II" and "cellulose IV," can be distinguished from each other based on Raman spectroscopy. It was found that the transformations in crystal form tended to occur in early stages of heating, and that they became more rapid with increasing moisture. However, no evidence has been collected regarding the type of cellulose crystals existing within practical samples of recycled paper, or whether or not such distinctions can explain differences in paper properties.

\section{Auto-crosslinking}

Some researchers still have trouble believing that the hydrogen bonding mechanism, given the inherent reversibility of hydrogen bonds, truly can explain why closed pores fail to open up again. If one thinks of the hydrogen bonding occurring in zipper-like fashion, these researchers are, in effect, seeking to find an explanation as to why bonded regions between previously separated elements of cellulosic material don't gradually "unzip" during protracted exposure to aqueous solution.

Back and Klinga (1963) were perhaps the first to consider the nature of covalent bonds that can form within cellulosic materials that are strongly heated. These authors observed that heating of papermaking fibers at $190{ }^{\circ} \mathrm{C}$ in dry air caused permanent shrinkage, from which the fibers did not recover when rewetted. The heated fibers also had reduced bonding potential for the formation of recycled paper. Though no detailed mechanism was proposed, the term "auto-crosslinking" was coined to describe the phenomenon (Nazhad and Paszner 1994). Back (1967) later suggested that the effect was due to formation of ester bonds between carboxyl groups and hydroxyl groups within the fibers (see also Ruffini 1967).

In support of the idea of ester bond mechanism, it is well known that ester bonds form when cellulose is heated above about $150{ }^{\circ} \mathrm{C}$ in the presence of poly-acids, such as polyacrylic acid or citric acid (Caulfield 1994; Mao and Yang 2001). Strong heating in the presence of monomeric, multifunctional acids, such as citric acid, yields relatively brittle cellulosic materials, whereas heating in the presence of long-chain polyacids can yield tough paper, having a high degree of wet-strength (Caulfield 1994, Xu et al. 1999). It has not been shown, however, that such a mechanism can be important under the usual 
conditions of paper drying, or at the much lower levels of carboxylic groups ordinarily present in, say, the hemicellulose component of papermaking fibers.

\section{Lactone formation}

Possibly the most radical chemical-based explanation that has been offered to account for the irreversibility of pore closure when kraft fibers are dried is that of Diniz et al. (2004). Based on the observation that sugar-like molecules have a high propensity for formation of lactones, these authors proposed that lactones also can play an important role in cross-linking of cellulosic material. In principle, according to these authors, lactone cross-links can be expected to form between carboxyl groups, in their associated form, and nearby hydroxyl groups, forming a cyclic ester, i.e. a lactone.

Perhaps the reason that the proposal of Diniz et al. (2004) has not received wider attention is that it does not offer an explanation as to why irreversible hornification readily occurs in the case of very low yield chemical pulps. To a first approximation, the carboxyl group content of papermaking fibers tends to decrease with decreasing yield (Herrington and Petzold 1992; Lloyd and Horne 1993). In other words, pulping and bleaching processes, as a general rule, tend to remove acidic groups, leaving behind a higher purity cellulose residual, which is lower in carboxyl content. Lindström and Carlsson (1982) demonstrated strong hornification in the case of highly carboxylated fibers when they were dried in their protonated form. However, such hornification was no more severe in comparison to the case of fibers having much lower levels of acidic groups. Also, there has been no evidence of wet-strength development when paper is dried under acidic papermaking conditions (e.g. $\mathrm{pH} 4$ to 6) at ordinary temperatures that a paper web reaches during papermaking (e.g. not much above the boiling point of water).

\section{Colloidal forces and pore closure}

Allan and Ko (1995) carried out an interesting analysis in an attempt to find out whether short-range forces of interaction between facing surfaces might account for the closure of tiny pores, as well as for their inability to re-open when dried fibers are placed back into water. In principle, short-range van der Waals forces of attraction can be expected to work in concert with hydrogen bonding and other forces that may act to hold facing surfaces of cellulose in contact with each other (Bergström et al. 1999; Claesson et al., 2003; Rojas et al. 2005).

\section{Depolymerization, Hydrolytic Scission}

As described by Page (1969), paper's strength may be limited either by the strengths of individual fibers or by the number of bonds that form between them. So far our discussion has been focused on the latter quantity. Howard and Bichard (1992) showed that the zero-span dry and wet tensile strength (considered to be measures of the individual fiber strength) remained constant for both high and low yield pulps over 5 recycling cycles. This laboratory experiment involved relatively mild conditions but utilized recirculation of white water fines during the preparation of handsheets. However, the same authors cited several other studies that disagreed with their results (see Howard and Bichard, 1992). The differences were attributed to different recycling 
procedures used. In some of these studies, the decrease in fiber strength was about 15$20 \%$ after multiple recycles.

When fibers are exposed to acidic conditions, especially in the presence of high humidity or moisture, the fibers themselves can be severely weakened (Back 1978). As shown by various authors, such effects often can be correlated to reductions in molecular mass (Kato and Cameron 1999; Ackermann et al. 2000). The effect is illustrated schematically in Fig. 6.
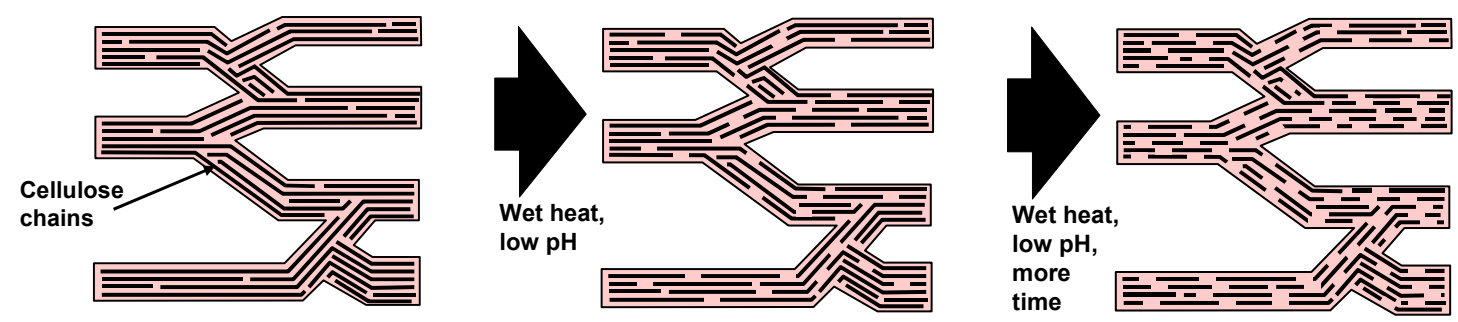

Figure 6. Schematic illustration of hydrolytic cleavage of cellulose chains within a "fringed micelle" structure of cellulose in a kraft fiber cell wall. A small amount of hydrolysis may go unnoticed, but eventually the fibers become brittle and susceptible to mechanical damage (Kato and Cameron 1999).

Because the time that paper is exposed to intense heat during drying is short, no more than a couple of minutes on a conventional paper machine, it is reasonable to question whether this is sufficient time for significant hydrolysis of cellulosic chains to take place. It has been shown that the loss of degree of polymerization (DP) in cellulosic wet fibers exposed to high temperature without drying tends to be much greater in comparison to the loss of DP if the same fibers are permitted to dry (Klungness and Caulfield 1982; Welf et al. 2005). However, as shown by both of these studies, there still can be substantial loss of molecular mass even if the fibers are dried in air at temperatures within the range of conventional papermaking. Klungness and Caulfield (1982) observed significant loss of DP during drying only in the case of bleached pulp. By contrast, Hubbe et al. (2003) observed significant losses in DP during drying of both bleached and unbleached kraft pulps. Due to a much greater initial chain length of cellulose molecules in the case of the unbleached kraft fibers, the relative change in DP appeared to be greater. Example calculations were provided, showing that the greater relative loss of DP in the case of a higher chain length is consistent with what would be expected based on random cleavage at a fixed rate in both cases.

Unfortunately, the problem of acid hydrolysis of paper does not end after the paper has been dried. Rather, paper can continue to suffer from hydrolysis during storage and use, especially if it has an acidic $\mathrm{pH}$, based on aqueous extraction or surface-pH tests (McComb and Williams (1981). Williams (1980) attributed the affect to acid hydrolysis of amorphous regions of the cellulose within the fibers. The good news is that this kind of degradation of cellulose chains easily can be minimized by producing the paper under neutral or weakly alkaline pH conditions (McComb and Williams 1981; Hubbe 2005a). 


\section{Redistribution of Wood Components}

Along with hornification and hydrolysis, the third major change that can distinguish recycled fibers from freshly prepared fibers, according to Back (1978), is redistribution of wood-derived materials. Such redistribution can be expected to be especially significant in the case of mechanically pulped fibers, which retain a substantial portion of the wood resins that were originally present. However, as papermakers know well, substantial amounts of triglyceride fats, fatty acids, resin acids, and unsaponifiable materials are also found in kraft and sulfite pulps, especially in the case of unbleached pulps.

\section{Rehydrophobization}

A potentially problematic consequence of redistribution, and further chemical reactions involving wood-resins in paper is called "self-sizing" (Swanson and Cordingly 1959; Aspler et al. 1985). This phenomenon manifests itself as an increased resistance to wetting. Though, for some types of paper products, self-sizing even can be considered to be an advantage, other types of products require rapid spreading and penetration of aqueous glues or of spilled aqueous materials. For instance, corrugating medium, as used in the production of shipping containers, needs to be able to rapidly absorb aqueous starch-based glue. Poor glue reception of the paper surface has generally been attributed the presence of fatty and resin acids on fiber surfaces in the paper. Such materials may have migrated to the fiber surfaces during paper formation, drying, or storage. If aluminum species also are present at the paper surface, then it is reasonable to expect that such aluminum can act as a mordant, holding onto the carboxylate groups of the wood resins and orienting the hydrophobic groups outward from the fiber surfaces. The mechanism is illustrated in Fig. 7. One of the ways that papermakers can overcome the effects of selfsizing, when the effect is undesirable, is by adding surfactants. It also has been noted that self-sizing problems usually are not significant after recovered fibers have been de-inked, a process that tends to remove hydrophobic wood-derived materials (Webb 1992).
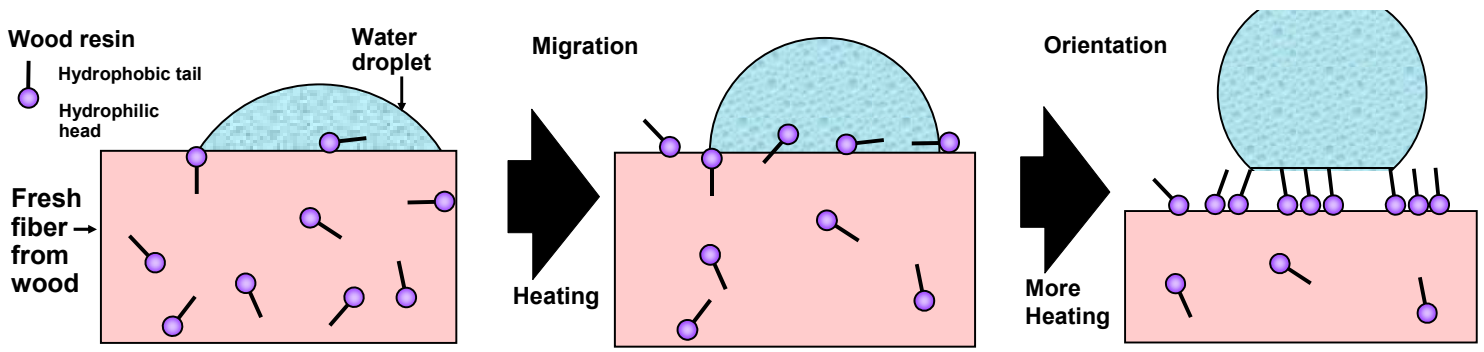

Figure 7. Schematic illustration of how surface-active agents, generally hydrophobic resins present in the wood-derived material, can be expected to migrate to fiber surfaces, gradually rendering them hydrophobic. The hydrophobic character can be made apparent by observing the initial contact angles of water droplets. (wood resin molecular size not to scale)

In support of the ideas given above, Swanson and Cordingly (1959) demonstrated that paper became much more hydrophobic after exposure to vapors of stearic acid. It was shown that radioactively tagged stearic acid molecules were able to diffuse through several layers of paper, rendering all of them hydrophobic, though to an extent that decreased with distance. Brandal and Lindheim (1966) showed, on the other hand, that 
the strength potential of mechanical fibers could be increased substantially by extracting the wood resins from mechanical pulp fibers. Tze and Gardner (2001b) quantified changes in wettability of cellulose fibers by means of dynamic contact angle (DCA) measurements and inverse gas chromatography (IGC). The DCA measurements were judged to be more useful in terms of quantifying changes in hydrophobicity, in addition to changes in the degree of expression of acidic and basic groups at fiber surfaces.

A hopeful aspect related to the effects just described is that sometimes they become less important when paper is recycled. Thus Singh and Roy (1996) found lower and lower levels of extractives in mechanical pulp furnish during successive generations of recycling in the lab. Even if one makes allowance for the fact that lab tests often involve very clean water, it makes sense that the importance of wood-derived pitch-like materials should decrease relative to other matters during repeated recycling. Also significant is the extraction of the hydrophobic materials into the recycling process water system, a very likely source of deposits on papermaking equipment (Hubbe et al. 2006.)

\section{Fines and surface composition}

Papermakers have long understood that both the quality and the level of cellulosic fine materials can affect paper's strength characteristics (Laivins and Scallan 1996; Retulainen et al. 2002; Pruden 2005). The effects of fines on paper recycling has remained less certain (Laivins and Scallan 1996). For instance, Rundlöf el al. (2000) showed that the fines fraction present in mechanical pulp can contain such a high level of extractives that the paper strength is impaired, especially when the white water had been subjected to hydrogen peroxide bleaching. Nazhad (2004) carried out further research aimed at answering the question of whether the increased dry-strength of recycled TMP sheets might be attributable to fines generation. Unlike traditional experiments of this type, the fines fraction was removed before papermaking. Tests were carried out with pulp that had been delignified to different degrees, resulting also in different levels of extractives content. The results could be explained based on the extractives content of the sheets. It was concluded that reported increases in physical strength due to recycling of high-yield furnishes may be partly due the "surface condition," which would be affected by losses of extractives-rich, and lignin-rich fines during various unit operations.

\section{EFFECTS OF NON-CELLULOSIC SUBSTANCES}

Recycled fiber supplies can contain substantial quantities of materials that are unrelated to wood (Göttsching and Stürmer 1978a; Webb 1992; Ackermann et al. 2000; Venditti et al. 2000; Venditti et al. 2001; Stauffer et al. 2001; Putz et al. 2003). Many such components can be called "contaminants" relative to the intended use of the fibers (Scott 1989; Klungness 1993; Brink 1997; Watanabe and Mitsuhiro 2005; Venditti et al. 2005). Deposits that occur on the wetted surfaces of papermaking equipment often can be blamed on non-cellulosic components, though the problems often involve a combination of both wood-derived and other substances (Douek et al. 2003; Hubbe et al. 2006). 


\section{Papermaking Additives}

The effects of various chemical additives used during the production of paper are well known (Eklund and Lindström 1991; Scott 1996; Roberts 1996; Neimo 1999). However, two questions are worth asking: First, to what extent do such chemicals remain in or on fibers when they are recycled? Second, and perhaps more importantly, do chemicals that are recycled along with the fibers still exhibit significant effects on the resulting recycled paper?

\section{Hydrophobic sizing agents}

In the case of alkyl ketene dimer (AKD) sizing Sjöström and Ödberg (1997) found that hydrophobic effects partly survived laboratory processing conditions designed to simulate ordinary deinking. Depending on the level of treatment in the initial cycle, the amount of freshly added AKD could be reduced by $30-70 \%$, while achieving a given level of water holdout in recycled sheets.

The sizing properties of recycled fibers also can be affected by extraneous materials (Boone 1996). For example, residual surface-active agents that are used in deinking operations can be expected to make the recycled fibers more difficult to hydrophobize. If substantial quantities of recycled filler particles are present, then there may be a higher total surface area that needs to be covered by sizing molecules. Recycled paper sometimes contains high levels of anionic materials (Kuys and Zhu 1994), which have the potential to hurt the efficiency of retention of sizing agents and other finely dispersed components in the papermaking furnish.

Not all effects of recycled sizing agents are beneficial. Guest and Voss (1983) found that sizing with rosin and alum tended to decrease the bonding potential of the fibers when recycled. Though no debonding effect was observed when they instead used AKD for sizing, the relative advantage of using the reactive size was no longer detectable after another cycle of re-use of the fibers.

\section{Dry-strength agents}

Recent studies have shown that dry-strength chemicals, when they are recycled along with kraft fibers, still can contribute substantially to the strength of the resulting paper (Zhang et al. 2001, 2002; Hubbe et al. 2003a; Hubbe and Zhang 2005; Mocchiutti 2006). Such benefits can be found when the paper strength is compared to that of paper produced in parallel tests in which no dry-strength polymer was used during the initial papermaking. The recycled dry-strength chemicals do not prevent losses in water retention. However, when dried papers are reslurried, the residual effects of chemicals added during the first cycle can be relatively large, even in comparison to their contributions during the first cycle of papermaking with never-dried unbleached kraft pulp (Zhang et al. 2002). These results are attributed to a more critical importance of inter-fiber bonding ability in the case of dried and reslurried kraft fibers, which can be expected to develop a lower relative bonded area (RBA).

Especially promising results with respect to the strength of recycled sheets were obtained in cases where the chemicals either had a cationic charge, e.g. cationic starch, or there was combined treatment with a high-charge cationic polymer and an anionic drystrength chemical such as carboxymethylcellulose or a copolymer of acrylic acid and 
acrylamide (Zhang et al. 2002; Hubbe et al. 2003a). It is worth noting that a similar twocomponent treatment also can be applied directly to the wet end furnish when making paper from recycled furnish (Kimura and Hamada 1992). Grau et al. (1996) found that benefits due to treatment of the never-dried fiber with dry-strength additives was significant in the first and second cycles of fiber recovery, but the residual effect of strength agents added initially were not significant any more after three cycles of sheetforming, disintegration, and formation into the next generation of handsheets.

\section{Deinking Materials}

Efforts to improve the cleanliness, brightness, and other characteristics of recycled fibers, in preparation for their use in papermaking, usually result in substantial quantities of waste. Materials that can end up in sludge from such operations include fiber fines and mineral fillers, along with inks, stickies, and waxes. D'Souza et al. (1998) found that most of the metal content in recycling systems was introduced with various kinds of wastepaper, and almost all of the metals ended up in the sludge. As long as one is willing to sacrifice some yield, a higher reject rate during deinking generally results in a higher quality of recycled fibers (Cardwell and Alexander 1977).

As mentioned briefly at the start of this article, fibers obtained from printed papers, even after deinking, are never completely clean. In addition to ink, dirt, etc., one can expect that such fibers will contain traces of chemicals that were used during the recycling process. Hunold and Göttsching (1996) found that when deinking was carried out as part of multiple recycling steps, in which the paper also was printed during each cycle, the physical properties were not significantly degraded. On the other hand, the appearance of the multiply-recycled paper got worse and worse as a result of repeated printing and deinking cycles. Likewise Bouchard and Douek (1993) found that a typical deinking treatment did not cause significant changes to the physical properties of various different types of fibers. Alanko et al. (1995) found that de-inking chemicals actually could have a beneficial effect on inter-fiber bonding, which was attributed to the fact that they helped remove oleophilic materials from the fiber surfaces. Kofta and Miller (1993), testing another type of bleached kraft pulp found that fiber strength properties fell significantly as a result of repeated cycles of papermaking, deinking, and formation of new paper sheets.

The types of additives that are commonly used during the recycling of paper have been reviewed (Shrinath et al. 1991; Ferguson 1992b; Haynes and Röring 1998; Göttsching and Pakarinen 2000). In cases where substantial amounts of deinking surfactants fail to get washed from the pulp before it passes to the paper mill, the resulting pulp may be very difficult to size. In particular, certain nonionic surfactants often used for deinking tend to act as wetting agents, covering up and reversing the effects of hydrophobic sizing agents (Moyers 1991). Another commonly used set of deinking chemicals is based on combinations of fatty acids and calcium salt addition. Korpela (1999) showed that the release of significant amounts of such chemicals into a paper machine system can be expected to decrease paper strength and the operating efficiency of paper machines.

Another noteworthy effect of recycling operations is observed when high-yield waste fibers are bleached with hydrogen peroxide. The oxidative treatment tends to 
release large quantities of polygalacturonic acids (pectic acids), which can greatly increase the cationic demand of the furnish (Sundberg et al. 1998; Jiang et al. 2000). Another incremental contribution to cationic demand may come from phosphates, which are often used to chelate transition metal ions that otherwise would interfere with peroxide bleaching. Though, in principle, papermakers can use highly charged cationic additives to compensate for a high cationic demand of the process, in practice the addition of large amounts of charge-control additives is expensive and can result in pitchlike deposits. It makes sense to avoid sending large amounts of negatively charged colloidal and polymeric materials to the paper machine, where they can hurt retention efficiency and raise costs. By washing the pulp after peroxide bleaching, such problems can be greatly reduced.

\section{EFFORTS TO BLOCK THE EFFECTS OF DRYING}

Higgins and McKenzie (1963) carried out the first detailed evaluation of possible ways to inhibit the effects associated with drying of kraft or sulfite fibers. Four main approaches were explored, (1) blocking formation of new hydrogen bonds, (2) formation of hydrogen bonds of a type that can be reversed, (3) reduction of the surface tension forces present during drying, and (4) inhibition of the collapse of fibers.

One of the most effective, but not necessarily practical methods of preventing hornification involved drying chemical pulp fibers in the presence of high concentrations of low-mass sugars (Higgins and McKenzie 1963). It appears that the sugar molecules inhibit hornification by getting in the way of hydroxyl groups at the surfaces and within pores of fibers. In this way the sugar molecules block the development of extensive intra-fiber hydrogen bonds (see previous discussion in Crystallization as a "locking" mechanism). Higgins' and McKenzie's main findings, with respect to sugar treatments, have been confirmed more recently (Laivins and Scallan 1993; Zhang et al. 2001, 2004).

Klungness et al. (2000) followed similar logic when they precipitated calcium carbonate particles within the cell walls of fibers. By placing the mineral within the interior of the fibers, rather than on the surface, it was possible to achieve greater strength at any given level of filler. The "loaded" fibers retained higher WRV after they were dried, in comparison to ordinary fibers and conventional calcium carbonate filler.

A more aggressive, but generally more expensive way to minimize hornification effects involves chemical derivatization of the fiber surfaces before they are first made into paper (Laivins and Scallan 1993). Thus, Ehrnrooth et al. (1977) observed that fibers that had been partially acetylated did not lose their swelling ability to as great an extent when they were dried. Though acetylation normally would be expected to increase the hydrophobic character of cellulose, it can be expected that low levels of acetylation can have a greater incremental effect in terms of interrupting the regular structure of cellulose chains, thus inhibiting local formation of crystal-like domains. Gruber and Weigert (1998) showed likewise that hornification effects could be suppressed by pretreating the fibers with alpha, beta- unsaturated substances and amino derivatives.

Scallan (1998) reviewed a number of additional derivatization schemes including carboxymethylation. Carboxymethyl groups appear to be effective in blocking horni- 
fication, as long as the $\mathrm{pH}$ is high enough to dissociate the carboxyl groups (Lindström and Carlsson 1982; Laivins and Scallan 1993). It is reasonable to expect, in these cases, that the water-loving nature of carboxylate groups, in their sodium form, ought to promote rewetting and reswelling. Carboxylic acid groups are much less water-loving when in their associated form. This difference helps to explain why Lindström and Carlsson (1982) observed significant decreases in WRV when fibers were dried in their acidic, associated form, regardless of the density of acidic groups on the fiber surfaces.

\section{Hemicellulose content effects}

A practical approach to try to take advantage of the effects of $\mathrm{pH}$ and carboxylic groups at fiber surfaces, as just mentioned, involves selection of fibers having a naturally high level of negatively charged hemicellulose components. Thus, Oksanen et al. (1997) varied the amounts of xylan and glucomannan in a series of pulp samples. Though removal of the hemicellulose components did not hurt the properties of the original paper, the recycled sheets formed from fibers having low hemicellulose levels were much reduced in strength. Likewise, Cao et al. (1998) observed that pulps having higher pentosan content were inherently more recyclable. Those findings help to explain the relatively good retention of strength properties when wheat straw pulp is recycled (Aravamuthan and Greaves 1998; Garg and Singh 2004; Tschirner et al. 2007); wheat straw is known to have relatively high pentosan content. Related studies have shown that hemicellulose contents of pulps can decrease with repeated recycling (Eastwood and Clark 1978; Wistara and Young 1999; Qian et al. 2005), leading to concerns that the benefits of having a high hemicellulose content in the virgin pulp may be lost during repeated recycling.

\section{RESTORATIVE TREATMENTS}

Strategies based on preventing deterioration of fiber quality are seldom under the direct control of those who want to use the recovered fibers. Rather, paper recyclers usually are at the mercy of what becomes available in terms of wastepaper cost and quality. Thus, there is a critical need to enhance the properties of used fibers after they have been collected (Minor et al. 1993; Howarth 1994).

\section{Blending}

When dealing with recycled fibers, a practical approach is to blend them with other materials, including freshly pulped fibers. The blending of different fibers types, depending on product requirements, can be considered to be "business as usual" for papermakers. Almost every machine utilizes broke. The broke often contains fully dried paper that has not been made into saleable product, and this is a simple form of paper recycling. Because recycled kraft fibers tend to be stiff and deficient in bonding ability, it is reasonable to blend them with a proportion of well-fibrillated kraft fibers. For instance, it has been suggested to blend a portion of fresh wheat straw pulp with recycled fibers (Aravamuthan and Greaves 1998). 
As observed by Hawes and Doshi (1993) and Fjerdingen and Houen (1997), cellulosic fines that are freshly prepared as a result of refining tend to be especially effective for promoting bonding within paper. By contrast, it has been proposed to remove hornified fines before the recovered kraft stock is subjected to further refining (Szwarcsztajn and Przybysz 1976). Microscopic observations by Somwang et al. (2001) suggest that virgin fines can help fill in the spaces within and adjacent to fiber crossings, thus increasing the effective area of bonding between fibers. Peterson and Zhang (2000) observed that recycled fiber quality tended to go through an optimum in strength properties with increasing amounts of fines. Also, one should bear in mind that fines of the type produced by refining of kraft fibers tend to be especially deleterious to rates of dewatering (Laivins and Scallan 1996).

\section{Fractionation}

Fractionation is often mentioned as a promising strategy when dealing with papermaking pulp of low quality (Pekkarinen 1985; Minor et al. 1993; Youn et al. 2007). Proponents of fractionation seem never to have any difficulty in describing possible uses for the long-fiber fraction. The difficulty generally lies in figuring out a profitable use for the fraction that becomes enriched in fines or stickies. In some grades it may be possible to "hide" inks and stickies within a center ply, thus minimizing effects on paper machine runnability, as well as in product appearance. There have been some efforts to develop a technology in which fiber fractionation is performed using a combination of screens and cleaners to produce a long fiber fraction and a short fiber fraction that is useful in developing softness in tissue (Vinson et al. 2001; Byrd et al. 2002). However this technology has not been implemented.

\section{Re-swelling}

Given the tendency for recycled kraft fibers to have reduced water retention, reduced flexibility, and reduced bonding potential, a number of researchers have evaluated possible ways to restore such fibers to something approximating their former conditions. In a sense, such approaches aim to "re-swell" the hornified fibers.

\section{Re-refining}

As papermakers well know, often the most practical way to restore swelling, flexibility, and bonding potential to recycled cellulosic fibers consists of repeated compression and shearing action on the slurry, i.e. "refining" (Szwarcsztajn and Przybysz 1976; Minor et al. 1993; Nahzad 2004; Zhang et al. 2004). However, two points should be kept in mind. First, the fibers already may have been refined, earlier in their history. Second, recycled kraft fibers can be more prone to fragmentation than they were the first time around. If refining is carried out to a sufficient degree to meet the original strength characteristics, then one can expect that the drainage characteristics of the furnish will suffer greatly (Bovin et al. 1973; Ehrnrooth et al. 1977; Laivins and Scallan 1996). In some cases it may be beneficial to employ high-consistency refining strategies. Such conditions of refining can minimize damage to fibers and help to defibrillate the fiber surfaces (de Ruvo and Htun 1983). 
As was already demonstrated by Brecht (1947), additional refining can make up for only part of the strength potential that is lost when fibers are dried. A possible explanation is that refining of recovered kraft fibers induces morphological changes that are distinct from those that occur as a result of refining freshly produced kraft fibers. Different behavior can be expected based on morphological differences between recycled vs. never-dried kraft pulps (Billosta et al. 2006). Rather than re-open the submicroscopic pores that closed as a result of drying, it is likely that re-refining delaminates the fibers in new areas. Such an effect may explain why some investigators have found little or no reswelling when recycled fibers are refined. Thus, Bawden and Kibblewhite (1997) did not detect physical change in the dimensions of recycled kraft fiber cell walls in the course of refining. Klungness and Caulfield (1982) found that refining of such fibers restored the original surface area of the fibers, before they were dried, but not their specific volume.

Recent research findings suggest that it is possible to optimize refining conditions such that one can achieve high quality in the first cycle of papermaking, but also preserve the value of the fibers for later use. Thus, Kang and Paulapuro (2006) observed that rerefining of kraft fibers recycled under laboratory conditions was especially effective if, in the first cycle, those fibers had been refined in such a way as to fibrillate just the external surfaces. By contrast, if the fibers had been "internally fibrillated," using repeated compression of the wet fibers, the strength potential was substantially used up during the first cycle of papermaking.

Researchers have disagreed regarding whether the swelling ability of fines can be restored by refining (Szwarcsztajn and Przybysz 1976, 1978; Howard 1990; Laivins and Scallan 1996). It is difficult to imagine how a conventional refiner system would impart enough compression or shearing action on extremely small entities in order to alter their properties. Rather, it would seem more likely that most of the stresses within a refiner would be carried by the fibers that are present, since they are larger and thicker. Laivins and Scallan (1996) observed, however, that re-refining restored the swelling ability of both fibers and fines, even when the proportion of newly created fines was relatively small. The same study showed that cellulosic fines tend to hold onto about twice as much water, per unit mass, in comparison to fibers.

\section{Caustic treatment}

Besides refining, the second most reliable way to restore swelling and flexibility to cellulosic fibers has been to expose them to high $\mathrm{pH}$ conditions. For example, Weise et al. (1998) found that "cooking" of recycled kraft fibers under strongly alkaline conditions was more effective in restoring their properties, in comparison with refining or hot disintegration. These authors observed, however, that the restoration of the fiber characteristics lasted only for the next cycle of papermaking. Anything that was done to increase the swelling of the recycled fibers resulted in greater hornification the next time the fibers were dried. Ogden (1999) patented the combined use of pressure, high temperature, and refining. Bhat et al. (1991) found that a combination of alkaline conditions and high shear yielded optimal effect with a minimum of fines creation. Minor et al. (1993) obtained the most promising results under conditions of alkaline treatment that were sufficiently concentrated, causing significant delignification. Such strategies were judged to be more successful, in terms of enhancing the strength 
properties of recycled fibers, in comparison with the use of bonding agents added at the wet end.

By use of certain organic solvents it is possible to achieve even higher levels of fiber swelling, in comparison to alkaline aqueous solutions. Tze and Gardner (2001a) found that such an approach was quite effective in restoring not only the swollen nature of fibers, but also the free energy of their surfaces. Of the various solvents tests, formamide offered the best prospects as a possibly cost-effective treatment.

\section{Enzymatic Treatments to Restore Fiber Quality}

When papermakers treat recycled fibers with cellulase, their main goal usually is to allow water to drain more quickly during paper forming. Such an effect can increase the rate of production on drainage-limited paper machines. More importantly, faster drainage often makes it possible to apply higher levels of refining, while still running the paper machine at top speed. Studies have shown that a judicious choice of the enzyme dosage and the duration of treatment can make it possible to achieve significant freeness increases, while still not causing unacceptable levels of degradation to the fibers (Bhat et al. 1991; Eriksson et al. 1998; Choi and Wan 2001).

Mechanistic questions can be raised about the findings just cited, since some of the same effects sometimes have been achieved by inactive enzyme materials. Pala et al. (2001) obtained superior results when non-hydrolytic binding domains of cellulase were used instead of the active enzyme. Such an approach was able to produce fast drainage in combination with preservation of the fibers' inherent strength.

Other ways to promote faster dewatering of papermaking furnish were reviewed in the previous issue of this journal (Hubbe and Heitmann 2007). Though not usually regarded as ways to "restore fiber properties," drainage benefits not unlike those resulting from enzyme treatment can be obtained.

\section{Fiber Modification}

The words "fiber modification" have been used in various different senses, including covalent derivatization of fiber surfaces. In principle it should be possible to increase the bonding potential of recycled kraft furnish by carboxymethylation (Walecka 1956; Lindström and Carlsson 1982; Fors 2000) or by high-temperature treatment of the pulp with carboxymethyl-cellulose (CMC) (Laine et al. 2000, 2002, 2003; Ekevåg et al. 2004). Either of these approaches will tend to increase the negative charge character of the fiber surfaces, making the surfaces more swellable and more bondable. Several alternative ways to the same basic goals were cited in an earlier review (Hubbe 2006b). A practical question facing users of such strategies is whether such treatments are costeffective, considering the initially low value of some recycled fibers.

Potentially lower-cost approaches can be considered that do not require chemical reactions or high-temperature treatments. For instance, Torgnysdotter and Wågberg (2006) formed polyelectrolyte multilayers on the surfaces of hornified fibers. Higher dry-strength in the resulting paper was attributed to a combination of increased contact area and an increased surface free energy of the surfaces to be contacted (Wågberg et al. 2002; Eriksson et al. 2006). Although studies involving polyelectrolyte multilayers have 
helped to promote progress in understanding dry-strength treatments, it is not clear how such a treatment would be achieved in a paper mill.

An alternate approach has been demonstrated recently that has the potential to achieve the same objectives as just mentioned. The dry strength of paper handsheets could be increased greatly by successive treatment of the furnish with balanced amounts of cationic and anionic polyelectrolytes (Lofton et al. 2005; Lvov et al. 2006). The first additive was in excess of the adsorption capacity of the fibers. Follow-up tests showed that the effect was due to the in-situ formation of polyelectrolyte complexes in the pulp suspension, followed by deposition of those complexes onto fiber surfaces, where they functioned as bonding agents (Hubbe et al. 2005; Hubbe 2005b). If the polyelectrolytes were allowed to mix with each other even for a few seconds before their addition to the fiber suspension, then the resulting contribution to strength was only half of what could be achieved if the mixing took place in the presence of an agitated fiber suspension.

\section{CONCLUSIONS}

\section{Taking Advantage of Different Fiber Characteristics}

After considering the research findings covered in this article, it becomes apparent that recycled fibers - especially in the case of kraft pulps - tend to be somewhat different than they were just before the first cycle of papermaking. However, many of these effects are quite subtle. Also, there are many ways to overcome such differences. In short, as long as one takes adequate measures to remove unwanted materials, e.g. inks, stickies, and even filler and cellulosic fines, then it is often possible to substitute recycled fibers in place of freshly prepared fibers.

Recycled fiber's difference relative to virgin fiber sometimes can be counted as an advantage. The recycled fibers may be stiffer, have a reduced tendency to swell with water, and tend to be more dimensionally stable (Ackermann et al. 2000). The relatively non-conformable nature of many recycled kraft pulps explains why the resulting paper often has a low apparent density (Wahren and Berg 1972); this often can be considered as an advantage when making printing grades, file folder, boxboard, and other grades of paper. Finally, a lower degree of swelling of many recycled kraft pulps can translate into lower energy expenditure in the dryer section of a paper machine (Cameron and Zwick 2003). As has been discussed in this article, deficiencies with respect to inter-fiber bonding actually can be overcome in numerous ways, including the use of wet-end additives or blending with refined, never-dried fibers. It is appropriate to understand that different fiber types, such as hardwood, softwood, mechanically pulped, chemically pulped, bleached, and non-bleached and of course, recycled forms of these, all will have different properties and will be suited for different applications. The judicious use of recycled fibers in applications in which they perform well and are economical is an essential task for the papermaker.

\section{Recyclability and Responsible Use}

Something else that becomes clear from considering the wide variety of research cited in this article is that the recycling of paper involves many compromises. As was 
noted in an editorial piece in this journal (Hubbe 2007), it can be quite complicated to determine the most appropriate, and even the most ethical way to deal with the recycling of paper. Success of any recycling program depends, to a large extent, on the responsible actions taken by the original producer of the paper, the printer, the user, and even the care taken in collection of wastepaper. The activities of a paper recycler can be made unnecessarily ineffective by the introduction of hard-to-remove stickies, inks, waxes, and other even more problematic materials (Watanabe and Mitsuhiro 2005).

But recycling is not the only possible choice. Another way to capture the potential value of waste fibers is to use them as a source of energy. Yet another approach is to avoid over-production of items that aren't actually used, as in the case of certain newspaper segments that remain unread in a given household. This review article has demonstrated that a great deal of progress has been achieved within the paper recycling industry in meeting the needs of customers in a cost-effective way, using renewable resources, and taking steps to minimize environmental impacts by using the resource multiple times.

\section{REFERENCES CITED}

Ackermann, C., Göttsching, L., and Pakarinen, H. (2000). "Papermaking potential of recycled fiber," in L. Göttsching H. Pakarinen (eds.), Recycled Fiber and Deinking, Papermaking Sci. Technol. Ser., Fapet Oy, Helsinki, Ch. 10, 358-438.

Aggrebrant, L. G., and Samuelson, O. (1964). "Penetration of water-soluble polymers into cellulose fibers," J. Appl. Polymer Sci. 8(6), 2801-2812.

Alanko, K., Paulapuro, H., and Stenius, P. (1995). "Recyclability of thermomechanical pulp fibers," Paperi Puu 77(5), 315-317, 319, 321, 323-325, 327-328.

Alince, B., and van de Ven, T. G. M. (1997). "Porosity of swollen pulp fibers evaluated by polymer adsorption," in The Fundamentals of Papermaking Materials, Trans. $11^{\text {th }}$ Fundamental Research Symp, Cambridge, 1997, Baker, C. F. (ed.), Pira International, Leatherhead, Surrey, UK.

Allan, G. G., and Ko, Y. C. (1995). "The Microporosity of pulp. The forces influencing the intra- and inter-fiber pore structure and pore size distribution in pulp and paper," Cellulose Chem. Technol. 29(4), 479-485.

Andreasson, B., Forsström, J., and Wågberg, L. (2003). “The porous structure of pulp fibers with different yields and its influence on paper strength," Cellulose 10( ), 111123.

Anon. (1981). "Water retention value (WRV)," TAPPI Useful Methods, UM 256.

Anon. (2000). "Water retention value (WRV)," Scandinavian Pulp, Paper and Board Testing Committee, SCAN-C 62:00.

Aravamuthan, R., and Greaves, J. S. (1998). "Effect of multiple recycles on wheat straw fibers," Proc. TAPPI Pulping Conference, 25-29 Oct., TAPPI Press, Atlanta, Vol. 1, $16 \mathrm{p}$.

Aspler, J. S., Chauret, N., and Lyne, M. B. (1985). "Mechanism of self-sizing of paper," in Papermaking Raw Materials, Punton (ed.), Vol. 2, 707-727.

Atalla, R. H. (1977). "The full potential of native cellulose fibers," Southern Pulp and Paper Manufacturer 40(8), 12-15. 
Atalla, R. H., Ellis, J. D., and Schroeder, L. R. (1984). "Some effects of elevated temperatures on the structure of cellulose and its transformation," J. Wood Chem. Technol. 4(4), 465-482.

Back, E. L. (1967). "Thermal auto-crosslinking in cellulose material," Pulp Paper Mag. Can. 68( ), T165-T171.

Back, E. L. (1978). "Discussion," in Fiber-Water Interactions in Paper-Making, Trans. Symp. Oxford, Sept. 1977, Tech. Div. British Paper and Board Ind. Fed., London, Vol. 2, 873 .

Back, E. L., Htun, M. T., Jackson, M., and Johanson, F. (1967). "Ultrasonic measurements of the thermal softening of paper products and the influence of thermal auto-cross-linking reactions," Tappi 50(11), 542-547.

Back, E. L., and Klinga, L. O. (1963). "The effect of heat treatment on internal stresses and permanent dimensional changes of paper," Tappi 46(5), 284-288.

Backström, M., Fellers, C., and Htun, M. (1999). "Influence of kappa number and surface energy on paper-to-paper friction," Nordic Pulp Paper Res. J. 14(3), 204-208.

Bawden, A. D., and Kibblewhite, R. P. (1997). "Effects of multiple drying treatments on kraft fibre walls," J. Pulp Paper Sci. 23(7), J340-J346.

Bayer, R. (1996). "Effect of multiple recycling on selected properties of TMP and CTMP," Allg. Papier-Rundschau: APR 120(27), 739-740, 742, 744-746.

Bergström, L., Stemme, S., Dahlfors, T., Arwin, H., and Ödberg, L. (1999). "Spectroscopic ellipsometry characterization and estimation of the Hamaker constant of cellulose," Cellulose 6(1), 1-13.

Berthold, J., and Salmén, L. (1997). "Effects of mechanical and chemical treatments on the pore-size distribution in wood pulps examined by inverse size-exclusion chromatography," J. Pulp Paper Sci. 23(6), J245-J254.

Bhat, G. R., Heitmann, J. A., and Joyce, T. W. (1991). "Novel techniques for enhancing the strength of secondary fiber," Tappi J. 74(9), 151-157.

Billosta, V., Brandström, J., Cochaux, A., Joseau, J.-P., and Ruel, K. (2006). "Ultrastructural organization of the wood cell wall can explain modifications caused in fibers during the pulping process," Cellulose Chem. Technol. 40(3-4), 223-229.

Bobalek, J. F., and Chaturvedi, M. (1989). "The effects of recycling on the physical properties of handsheets with respect to specific wood species," Tappi J. 72(6), 123 125.

Bonham, J. S., and Rolniczak, B. (2005). "Accelerated ageing of copy papers containing recycled fiber," Proc. 59th Appita Annual Conference, 13th ISWFPC: International Symposium on Wood, Fibre and Pulping Chemistry, May 16-19 2005, Auckland, New Zealand, Vol. 1, 407-413, 4A42.

Boone, S. R. (1996). "How does the use of recycled fiber affect sizing chemistry - Both internal sizing and surface or on-machine sizing?" Prog. Paper Recycling 5(2), 99102.

Bouchard, J., and Douek, M. (1993). "Effects of recycling on the chemical properties of pulps," Res. Forum Recycling (2nd CPPA), 5-7 Oct., 23-29.

Bovin, A., Hartler, N., and Teder, A. (1973). "Changes in pulp quality due to repeated papermaking," Paper Technol. 14(10), 261-264. 
Braitsford, S. F. (1978). "Discussion," in Fiber-Water Interactions in Paper-Making, Trans. Symp. Oxford, Sept. 1977, Tech. Div. British Paper and Board Ind. Fed., London, Vol. 2, 853.

Brandal, J., and Lindheim, A. (1966). "The influence of extractives in groundwood pulp on fiber bonding," Pulp Paper Mag. Can. 67(10), T431-T435.

Brecht, W. (1947). "Changes in paper properties due to mechanical regeneration," Papier $1(1 / 2), 16-21 ;(3 / 4), 60-63$.

Brink, M. W. (1997). "Recycled fiber use vs. paper machine runnability - You can win!" Proc. TAPPI 1997 Engineering and Papermakers Conf., 51-58.

Byrd, M., Pawlak, J., Jameel, H., Venditti, R. A., Chang, H. M., and Park, S. (2002). "The effect of operating variables on the fractionation characteristics of a hydrocyclone," TAPPI Pulping Conf. Proc., San Diego, CA, 1398-1413.

Cameron, J. H., and Zwick, T. R. A. (2003). "The effect of fiber recycling on paper drying," TAPPI Spring Technical Conference and Exhibit, May 11-15 2003, Chicago, IL, United States, TAPPI Press, Atlanta, 537-548.

Campbell, W. B. (1947). "Academic aspects of paper stock preparation," Tech. Assoc. Papers 30(6), 177-180.

Campbell, W. B. (1959). "The mechanism of bonding," Tappi 42(12), 999-1001.

Cardwell, R. D., and Alexander, S. D. (1977). "Effects of recycling on softwood kraft pulp properties," Appita 30(4), 327-333.

Carlsson, G., and Lindström, T. (1984). "Hornification of cellulose fibers during wet pressing," Swensk Papperstidn. 87, R119-

Cao, B., Tschirner, U., and Ramaswamy, Sh. (1998). "Impact of pulp chemical composition on recycling, Tappi J. 81(12), 119-127.

Cao, B., Tschirner, J., and Ramaswamy, S. (1999). "Study of changes in wet-fiber flexibility and surface condition of recycled fibers," Paperi ja Puu/Paper and Timber 81(2), 117-122.

Cardwell, R. D., and Alexander, S. D. (1977). "Effects of recycling on softwood kraft pulp properties," Appita 30(4), 327-333.

Caulfield, D. F. (1994). "Ester crosslinking to improve wet performance of paper using multifunctional carboxylic acids, butanetetracarboxylic and citric acid," Tappi J. 77(3), 205-212.

Chakravarthi, S. N., Schroeder, L. R., Unbehend, J. E., and Ramarao, B. V. (1995). "Changes in TMP on recycling," Progress in Paper Recycling 4(2), 62-75.

Chatterjee, A., Lee, J., Roy, D. N., and Whiting, P. (1991). "Effects of recycling on the surface characteristics of paper," Proc. TAPPI Intl. Paper Physics Conf., Kona, HI, TAPPI Press, Atlanta, Book 1, 129-142.

Choi, Y.-S., and Won, J. M. (2001). "Improvement of papermaking properties of recycled fiber with enzyme," Palpu Chongi Gisul/Journal of Korea Technical Association of the Pulp and Paper Industry 33(1), 30-37.

Cildir, H., and Howarth, P. (1972). "The effect of re-use on paper strength," Paper Technol. 13(10), 333-335.

Claesson, P. M., Dedinaite, A., and Rojas, O. J. (2003). "Polyelectrolytes as adhesion modifiers," Advances in Colloid and Interface Science 104, 53-74. 
Clark, J. d'A. (1985). "Bonding of cellulose surfaces," in Pulp Technology and Treatment for Paper, $2^{\text {nd }}$ Ed., Miller Freeman, San Francisco, Ch. 7, pp. 145-159.

Cullinan, H. T. (1992). “Age distribution of recycled fiber," Appita J. 45(1), 6-8.

De Ruvo, A., and Htun, M. (1983). "Fundamental and practical aspects of paper-making with recycled fibers," in The Role of Fundamental Research in Paper Making, J. Brander (ed.), Mechanical Engineering Pub., Ltd., London, Vol. 1, 195-225.

Diniz, J. M. B. F., Gil, M. H., and Castro, J. A. A. M. (2004). "Hornification - Its origin and interpretation in wood pulps," Wood Sci. Technol. 37(6), 489-494.

Douek, M., Sithole, B., and Banerjee, S. (2003). "Survey of deposits and contaminants in mills using recycled fiber," Prog. Paper Recycling 13(1), 12-22.

D'Souza, V. A., Hand, V. C., and Schaefer, R. L. (1998). "Concentration of metals entering and leaving a recycled paper deinking mill," Prog. Paper Recycling 7(3), 22-32.

Dulemba, M., Qi, D., and Aravamuthan, R. (1999). "The effect of repeated drying and wetting on single fiber flexibility," Prog. Paper Recycling 9(1), 38-45.

Eastwood, F. G., and Carke, B. (1978). "Handsheet and pilot machine recycling degradation mechanisms," in Fiber-Water Interactions in Paper-Making, Trans. Symp. Oxford, Sept. 1977, Tech. Div. British Paper and Board Ind. Fed., London, Vol. 2, 835-855.

Eichinger, R. (1981). "Strength potential of recycled paper pulp," Wochenbl. Papierfabr. 109(18), 682-685.

Ehrnrooth, E., Htun, M., and de Ruvo, A. (1977). "Esterification as a means of improving the properties of once-dried fibers," in Fiber-Water Interactions in Papermaking, Trans. BPBIF Symp., Oxford, 899-915.

Ekevåg, Lindström, T., Gellerstedt, G., and Lindström, M. (2004). “Addition of carboxymethylcellulose to the kraft cook," Nordic Pulp Paper Res. J. 19(2), 200-207.

Eklund, D., and Lindström, T. (1991) Paper Chemistry, DT Paper Science Publ., Grankulla, Finland.

Ellis, R. L., and Sendlachek, K. M. (1993). "Recycled versus virgin-fiber characteristics: A comparison," in Secondary Fiber Recycling, R. J. Spangenberg (ed.), TAPPI Press, Atlanta, GA, Ch. 2, 7-19.

Emsley, A. M., Heywood, R. J., Ali, M., and Eley, C. M. (1997). “On the kinetics of degradation of cellulose," Cellulose 4, 1-5.

Eriksson, L. A.., Heitmann, J. A., and Venditti, R. A. (1998). "Freeness improvement of recycled fibers using enzymes with refining," Proceedings of the 1997 ACS Symposium, Apr 13-17 1997, San Francisco, CA , USA, 41-54.

Eriksson M., Torgnysdøtter A., and Wågberg, L. (2006). "Surface modification of wood fibers using the polyelectrolyte multilayer technique: Effects on fiber joint and paper strength properties," Industrial \& Engineering Chemistry Research 45 (15), 52795286.

Etzler, F. M., Buche, M., Bobalek, J. F., and Weiss, M. A. (1995). "Surface free energy of paper and inks: Printability issues," Proc. TAPPI 1995 Papermakers Conf., TAPPI Press, Atlanta, 383-394.

Fahmy, Y., and Mobarak, F. (1971). “On fine structure of cellulose fibers," Svensk Papperstidn. 74(1), 2-9. 
Fan, L. T., Lee, Y.-H., and Beardmore, D. H. (1980). "Mechanisms of the enzymatic hydrolysis of cellulose: Effects of major structural features of cellulose on enzymatic hydrolysis," Biotechnol. Bioeng. 22(1), 177-199.

Felix, J. M., and Gatenholm, P. (1993). "Characterization of cellulosic fibers using inverse gas chromatography," Nordic Pulp Paper Res. J. 8(1), 200-203.

Ferguson, L. D. (1992a). "Effects of recycling on [mechanical RFP] strength properties," Paper Technol. 33(10), 14-20.

Ferguson, L. D. (1992b). “Deinking chemistry: Parts 1, 2,” Tappi J. 75(7), 75-83; (8), 49-58.

Ferguson, L. D. (1994). "Effects of recycling on the strength properties of paper," Wochenbl. Papierfabr. 122(4), 132-138.

Fjerdingen, H., and Houen, P. J. (1997). "On the effect of recycling of kraft paper on selected fines properties," Recycling Symp., TAPPI Press, Atlanta, 299-311.

Forester, W. K. (1985). "Recycling of neutrally sized calcium carbonate filled paper," Proc. TAPPI 1985 Pulping Conf., TAPPI Press, Atlanta, 141-144.

Fors, C. (2000). The Effect of Fiber Charge on Web Consolidation in Papermaking, Licentiate Thesis, Royal Inst. of Technology, Stockholm.

Gallay, W. (1950). "The measurement and significance of swelling of cellulose fibers," Tappi 33(9), 425-429.

Garg, M., and Singh, S. P. (2004). "Recycling potential of bagasse and wheat straw pulps," Tappi J. 3(9), 25-31.

Garg, M., and Singh, S. P. (2006). "Reasons of strength loss in recycled pulp," Appita J. 59(4), 274-279.

Garvin, S. P., Jr., and Pantaleo, P. F. (1976). "Measurements and evaluation of dryer section performance," Proc. TAPPI Engineering Conf., TAPPI Press, Atlanta, Book 2, 125-133.

Gavazzo, G., Valade, J., Law, K., and Paris, J. (1995). "Behavior of thermomechanical pulps, chemithermomechanical pulps, and chemimechanical pulps of black spruce [Picea mariana] during recycling," $28^{\text {th }}$ Annual Pulp and Paper Conference), November 6-10, 1995, Sao Paulo, Brazilian Pulp and Paper Technical Association (ABTCP), 343-357.

Gerspach, W., Luo, C., and Göttsching, L. (1993). "Modeling of the age distribution of fibers in recycling systems," Papier 47(6), 288-299.

Göttsching, L. (1995). "Raw materials for papermaking," in The First EcoPaperTech, Helsinki, Finland, June 6-9, 1995, The Finnish Pulp and Paper Res. Inst.

Göttsching, L., and Pakarinen, H. (2000). Recycled Fiber and Deinking, Papermaking Science and Technology Ser., No. 7, Fapet Oy, Helsinki.

Göttsching, L., and Stürmer, L. (1978a). "Physical properties of secondary fibers under the influence of their previous history, Part 1: Secondary fiber pulp in the context of technology and research" Wochenbl. Papierfabr. 106(21), 801-808.

Göttsching, L., and Stürmer, L. (1978b). "Physical properties of secondary fibers under the influence of their previous history. Part 2: Influence of multiple recycling," Wochenbl. Papierfabr. 106(23/24), 909-918.

Göttsching, L., and Stürmer, L. (1978c). "The effect of calendaring and supercalendering on the properties of secondary fibers," in Fiber-Water Interactions in Paper-Making, 
Trans. Symp. Oxford, Sept. 1977, Tech. Div. British Paper and Board Ind. Fed., London, Vol. 2, 877-897.

Grau, U., Schuhmacher, R., and Kleemann, S. (1996). "Effect of recycling and the performance of dry-strength agents," Wochenbl. Papierfabr. 124(17), 729-735.

Gregersen, Ø. W., Skinnarland, I., Johnsen, P. O., and Helle, T. (1995). "Qualitative methods for the study of lignin distribution in wood and surface layers of unbleached pulp fibers and paper," J. Pulp Paper Sci. 21(8), J285-J287.

Gruber, E., Großmann, and Schempp, W. (1996). "Interactions of synthetic cationic polymers with fibers and fillers. Part 1. The Effect of Adsorption," Wochenbl. Papierfabr. 124(1), 4-6,8,10-11.

Gruber, E., and Weigert, J. (1998). "Chemical modification of pulp to reduce its hornification tendency," Papier 52(Suppl. 10A), V20-V26.

Guest, D. A., and Voss, G. P. (1983). "Improving the quality of recycled fiber," Paper Technol. Ind. 24(7), 256-260, 268.

Guest, D., and Weston, J. (1990). 'I dried my fibers yesterday, now I can't do nothin' with 'em," in Recycling Paper, from Fiber to Finished Product, TAPPI Press, Vol. 1, $169-175$.

Gullichsen, J., and Fogelholm, C.-J. (eds.) (1999). Chemical Pulping, Papermaking Science and Technology ser., No. 6, Fapet Oy, Helsinki.

Gurnagul, N. (1995). "Sodium hydroxide addition during recycling: Effects on fiber swelling and sheet strength," Tappi J. 78(12), 119-124.

Gurnagul, N., Ju, S., and Page, D. H. (2001). "Fiber-fiber bond strength of once-dried pulps," J. Pulp Paper Sci. 27(3), 88-91.

Haggkvist, M., Li, T. Q., and Ödberg, L. (1998). "Effects of drying and pressing on the pore structure in the cellulose fiber wall studied by H-1 and H-2 NMR relaxation," Cellulose 5(1), 33-49.

Hartler, N. (1995). "Aspects on curled and microcompressed fibers," Nordic Pulp Paper Res. J. 10(1), 4-7.

Hatakeyama, H., and Hatakeyama, T. (1981). "Structural change of amorphous cellulose by water treatment and heat treatment," Makromol. Chem. 182(6), 1655-1668.

Hattula, T. (1986). "Crystallization and disordering of wood cellulose during hydrothermal treatment," Paperi Puu 68(11), 847-850.

Hawes, J. M., and Doshi, M. R. (1993). "Contribution of different types of fines to the properties of handsheets made from recycled paper," Prog. Paper Recycling 3(1), 96105.

Haynes, R. D., and Röring, A. (1998). "Pulper chemistry: The key to improved deinking in North America," Proc. TAPPI 1998 Recycling Symp., 29-37.

Higgins, H. G., and McKenzie, A. W. (1963). "The structure and properties of paper. XIV. Effects of drying on cellulose fibers and the problem of maintaining pulp strength," Appita 16(6), 145-164.

Hipple, B. (1991). "Fine paper properties and the effects of wet-end starch when using deinked recycled fiber in an alkaline system," Tappi J. 74(5), 79-84.

Herrington, T. M., and Petzold, J. C. (1992). "An investigation into the nature of charge on the surface of papermaking woodpulps. 2. Analysis of potentiometric titration data," Colloids Surf. 64(2), 109-118. 
Horn, R. A. (1975). "What are the effects of recycling on fiber and paper properties?" Paper Trade J. 159(7/8), 78-82.

Horn, R A. (1995). "What are the effects of recycling on fiber and paper properties?" Prog. Paper Recycling 4(2), 76-82.

Houen, P. J., Helle, T., and Johnsen, P. O. (1993). "Effect of recycling of thermomechanical pulp on some pulp and handsheet properties," 18th International Mechanical Pulping Conference 1993: Proceedings, Oslo, Norway, Eucepa, 350-372.

Howard, R. C. (1990). “The effects of recycling on paper quality," J. Pulp Paper Sci. 16(5), J143-J149.

Howard, R. C. (1995). "The effects of recycling on pulp quality," in Technology of Paper Recycling, R. W. J. McKinney (ed.), Blackie Academic, London, Ch. 6, 180-203.

Howard, R. C., and Bichard, W. (1992). "The basic effects of recycling on pulp properties,” J. Pulp Paper Sci. 18(4), J151-J159.

Howarth, P., and Pycraft, C. J. H. (1978). "Discussion," in Fiber-Water Interactions in Paper-Making, Trans. Symp. Oxford, Sept. 1977, Tech. Div. British Paper and Board Ind. Fed., London, Vol. 2, 849-850.

Howarth, P. (1994). "Fundamental problem in recycling," Prog. Paper Recycling 3(3), 66-70.

Hubbe, M. A. (2005a). "Acidic and alkaline sizings for printing, writing, and drawing papers," The Book and Paper Group Annual 23, 139-151.

Hubbe, M. A. (2005b). "Dry-strength development by polyelectrolyte complex deposition onto non-bonding glass fibers," J. Pulp Paper Sci. 31(4), 159-166.

Hubbe, M. A. (2006a). "Sensing the electrokinetic potential of cellulosic fiber surfaces," BioResources 1(1), 116-149.

Hubbe, M. A. (2006b). "Bonding between Cellulosic Fibers in the Absence and Presence of Dry-Strength Agents - A Review," BioResources 1(2), 281-318.

Hubbe, M. A. (2007). "Incinerate, recycle, or wash and reuse," BioRes. 2(1), 1-2.

Hubbe, M. A., and Heitmann, J. A. (2007). "Review of factors affecting the release of water from cellulosic fibers during paper manufacture," BioResources 2(3), 500-533.

Hubbe, M. A., Jackson, T. L., and Zhang, M. (2003a). "Fiber surface saturation as a strategy to optimize dual-polymer dry strength treatment," Tappi J. 2(11), 7-12.

Hubbe, M. A., Moore, S. M., and Lee, S. Y. (2005). "Effects of charge ratios and cationic polymer nature on polyelectrolyte complex deposition onto cellulose," Indus. Eng. Chem. Res. 44(9), 3068-3074.

Hubbe, M. A., Rojas, O. J., and Venditti, R. A. (2006). "Control of tacky deposits on paper machines - A review," Nordic Pulp Paper Res. J. 21(2), 154-171.

Hubbe, M. A., Venditti, R. A., Barbour, R. L., and Zhang, M. (2003b). "Changes to unbleached kraft fibers due to drying and recycling," Prog. Paper Recycling 12(3), 11-20.

Hubbe, M. A., and Zhang, M. (2005). "Recovered kraft fibers and wet-end dry-strength polymers," Proc. TAPPI 2005 Practical Papermakers Conf., TAPPI Press, Atlanta, digital doc.

Huber, P., Carré, B., Petit-Conil, M., Fabry, B., and Bhattachargee, S. (2006). "Effect of the deinking process on physical properties of various wood-free recovered paper furnishes," Pulp Paper Can. 107(7-8), 34-40. 
Hulit, D. D. (1978). "Discussion," in Fiber-Water Interactions in Paper-Making, Trans. Symp. Oxford, Sept. 1977, Tech. Div. British Paper and Board Ind. Fed., London, Vol. 2, 851.

Hunold, M., and Göttsching, L. (1996). "Multiple recycling in pilot plant scale," Papier 50(10A), V82-V90.

Iyer, P. B., Sreenivasan, S., Chidambareswaran, P. K., Patil, N. B., and Sundaram, V. (1991). "Induced crystallization of cellulose in never-dried cotton fibers," J. Appl. Poly. Sci. 42(6), 1751-1757.

Jacob, P. N., and Berg, J. C. (1993). "Contact angle titrations of pulp fiber furnishes," Tappi J. 76(5), 133-137.

Jahan, M. S. (2003). "Changes of paper properties of nonwood pulp on recycling," Tappi J. 2(7), 9-12.

Jang, H. F., Howard, R. C., and Seth, R. S. (1995). "Fiber characterization using confocal microscopy - Effects of recycling," Tappi J. 78(12), 131-137.

Jayme, G. (1944). "Micro-swelling measurement in cellulosic pulp," Papier-fabr. / Wochenbl. Papierfabr. 6, 187-194.

Jayme, G., and Büttel, H. (1964). "The dependence of the water retention value (WRV) and the strength properties on the $\mathrm{pH}$ value of various bleached and unbleached pulps," Wochenbl. Papierfabr. 92(23/24), 718-727.

Jayme, G., and Büttel, H., (1968). "The determination and the meaning of water retention value (WRV) of various bleached and unbleached cellulosic pulps," Wochenbl. Papierfabr. 96(6), 180-187.

Jiang, Z.-H., van Lierop, B., and Berry, R. (2000). "Hexenuronic acid groups in pulping and bleaching chemistry," Tappi J. 83(1), 167-175.

Kang, T., and Paulapuro, H. (2006). "Recycle potential of externally fibrillated chemical pulp," Prog. Paper Recycling 15(2), 11-17.

Kato, K. L., and Cameron, R. E. (1999). "A review of the relationship between thermallyaccelerated ageing of paper and hornification," Cellulose 6(1), 23-40.

Kibblewhite, R. P. (1983). "The fibers of radiata pine mechanical pulps," Appita 36(4), 272-281.

Klungness, J. H., and Caulfield, D. F. (1982). "Mechanisms affecting fiber bonding during drying and aging of pulps," Tappi J. 65(12), 94-97.

Kimura, M., Hatakeyama, T, and Nakano, J. (1974). "DSC study on recrystallization of amporphous cellulose with water," J. Appl. Polym. Sci. 18(10), 3069-3076.

Kimura, Y., and Hamada, M. (1992). "Wet-end paper chemicals in a secondary fiber system," Proc. Pan-Pacific Pulp Paper Technol. Conf., Tokyo, Part B, 83-89.

Klofta, J. L., and Miller, M. L. (1993). "Effects of deinking on the recycle potential of papermaking fibers," Res. Forum Recycling ( $\left.2^{\text {nd }}\right)$, DAPPI, 5-7 Oct., 207-220.

Klungness, J. H. (1993). "Recycled-fiber properties as affected by contaminants and removal processes," Prog. Paper Recycling 3(1), 71-81.

Koning, J. W., and Godshall, W. D. (1975). "Repeated recycling of corrugated containers and its effect on strength properties," Tappi 58(9), 146-150.

Korpela, A. (1999). "The effects of fatty acid soaps on the properties of recycled mechanical and chemical pulp," Papier 53(10), 604-610. 
Kulshreshtha, A. K., Patel, A. R., Baddi, N. T., and Srivastava, H. C. (1977). "Studies on never-dried cotton," J. Polymer Sci. 15, 165-183.

Kuys, K., and Zhu, Q. (1994). "Surface chemistry of recycled paper furnishes," APPITA Ann. Gen. Conf. 48 ${ }^{\text {th }}, 409-414$.

Laine, J., Lindström, Glad Nordmark, G., and Risinger, G. (2000). "Studies on topochemical modification of cellulosic fibers. Part 1. Chemical conditions for the attachment of carboxymethyl cellulose onto fibers," Nordic Pulp Paper Res. J. 15(5), 520-526.

Laine, J., Lindström, Glad Nordmark, G., and Risinger, G. (2002). "Studies on topochemical modification of cellulosic fibers. Part 2. The effect of carboxymethyl cellulose attachment on fiber swelling," Nordic Pulp Paper Res. J. 17(1), 50-56.

Laine, J., Lindström, Glad Nordmark, G., and Risinger, G. (2003). "Studies on topochemical modification of cellulosic fibers. Part 5. Comparison of the effects of surface and bulk chemical modification and beating on pulp and paper properties," Nordic Pulp Paper Res. J. 18(3), 325-332.

Laivins, G. V., and Scallan, A. M. (1993). "The mechanism of hornification of wood pulps," in Products of Papermaking: Trans. $10^{\text {th }}$ Fund. Res. Symp., Oxford, Sept. 1993, C. F. Baker (ed.), Pira International, Leatherhead, Surrey, UK, Vol. 2, 1235 1259.

Laivins, G. V., and Scallan, A. M. (1996). "The influence of drying and beating on the swelling of fines," J. Pulp Paper Sci. 22(5), J178-184.

Law, K. N. (1996). "Study on cyclic reslushing of mechanical pulps," Prog. Paper Recycling 6(1), 32-38.

Law, K. N., Song, X. L., and Daneault, C. (2006). "Influence of pulping conditions on the properties of recycled fibers," Cellulose Chem. Technol. 40(5), 335-343.

Law, K., Valade, J. L., and Li, Z. (1995). "Recycling behavior of TMP - Effects of refining energy," Conf. Proc.: Refining 95: Third International Refining Conference, Atlanta, GA, Pira International, Leatherhead, United Kingdom, Vol. 2, 18 p.

Lee, H. L., and Joo, S. B. (2000). "The effect of recycling procedures of papermaking fibers and fines on the adsorption of cationic polyacrylamide," Nordic Pulp Paper Res. J. 15(5), 446-451.

Li, K. and Reeve, D. W. (2004a). "Determination of surface lignin of wood pulp fibres by X-ray photoelectron spectroscopy," Cellulose Chemistry and Technology 38(3-4), 197-210.

Li, K. and Reeve, D. W. (2004b). "Fluorescence labelling of lignin in the wood pulp fibre wall," Journal of Wood Chemistry and Technology, 24(2), 169-181

Li, K. and Reeve, D. W. (2005). "Analysis of lignin distribution across the fibre wall with confocal laser scanning microscopy," Cellulose Chem. Technol. 39(3), 211-223.

Li, K., Tan, X., and Yan, D. (2006). "Middle lamella remainders on the surfaces of various mechanical pulp fibres," Surface and Interface Analysis, 38, 1328-1335.

Li, T.-Q., Henriksson, U., and Ödberg, L. (1993). "Determination of pore sizes in wood cellulose fibers by ${ }^{2} \mathrm{H}$ and ${ }^{1} \mathrm{H}$ NMR," Nordic Pulp Paper Res. J. 8(3), 326-330.

Lindström, T., and Carlsson, G. (1982). "The effect of carboxyl groups and their ionic form during drying on the hornification of cellulose fibers," Svensk Papperstidn. 85(15), R146-R151. 
Lofton, M. C., Moore, S. M., Hubbe, M. A., and Lee, S. Y. (2005). "Polyelectrolyte complex deposition as a mechanism of paper dry-strength development," Tappi J $4(9), 3-7$.

Lloyd, J. A., and Horne, C. W. (1993). "The determination of fiber charge and acidic groups of radiata pine pulps," Nordic Pulp Paper Res. J. 8(1), 48-52, 67.

Lundberg, R., and de Ruvo, A. (1978a). "Influence of drying conditions on recovery of swelling and strength of recycled fibers," Svensk Papperstidn. 81(11), 355-358.

Lundberg, R., and de Ruvo, A. (1978b). "The influence of defibration and beating conditions on the paper making potential of recycled paper," Svensk Papperstidn. 81(12), 383-386.

Lvov, Y. M., Grozdits, G. A., Eadula, S., Zheng, Z. G, and Lu, Z. H. (2006). "Layer nanocoating of mill broken fibers for improved paper," Nordic Pulp Paper Res. J. 21(5), 552-557.

Lyne, L. M., and Gallay, W. (1950). "The effect of drying and heating on the swelling of cellulose fibers and paper strength," Tappi 33(9), 429-435.

Maloney, T. C., Li, T.-Q., Weise, U., and Paulapuro, H. (1997). "Intra- and inter-fiber pore closure in wet pressing," Appita J. 50(40), 301-306.

Maloney, T. C., Johansson, T., and Paulapuro, H. (1998a). "Removal of water from the cell wall during drying," Paper Technol. 39(6), 39-47.

Maloney T. C., Paulapuro, H., and Stenius P. (1998b), "Hydration and swelling of pulp fibers measured with differential scanning calorimetry," Nordic Pulp \& Paper Research Journal 13 (1), 31-36.

Malton, S., Kuys, K., Parker, I., and Vanderhoek, N. (1998). “Adsorption of cationic starch on eucalypt pulp fibers and fines," Appita J. 51(4), 292-298.

Mansito, O., Aguero, C., and Soa, M. (1992). "Recycling of bagasse pulps," O Papel 29, 69-70.

Mao, Z., and Yang, C. Q. (2001). "IR spectroscopy study of cyclic anhydride as intermediate for ester crosslinking of cotton cellulose by polycarboxylic acids. V. Comparison of 1,2,4-butanetricarboxylic acid and 1,2,3-propanetricarboxylic acid," $J$. Applied Polymer Sci. 81(9), 2142-2150.

Marton, J., and Marton, T. (1976). "Wet end starch: Adsorption of starch on cellulosic fibers," Tappi 59(12), 121-124.

Maximino, M. G., Formento, J. C., Adell, A. M., and Taleb, M. C. (2006). "Combined treatments to upgrade repulped long fiber kraft paper," Cellulose Chem. Technol. 40(6), 469-474.

McComb, R. E., and Williams, J. C. (1981). "The value of alkaline papers for recycling," Tappi 64(4), 93-96.

McKee, R. C. (1971). "Effect of repulping on sheet properties and fiber characteristics," Paper Trade J. 155(21), 34-40.

Middleton, S. R., and Scallan, A. M. (1994). "Filler retention and the specific surface area of fibers," Nordic Pulp Paper Res. J. 9(3), 156-160.

Milichovsky, M. (1990). "A new concept of chemistry refining processes," Tappi J. 73(10), 221-232.

Minor, J. L. (1994). "Hornification - Its origin and meaning," Prog. Paper Recycling 3(2), 93-95. 
Minor, J. L., Scott, C. T., and Atalla, R. H. (1993). "Restoring bonding strength to recycled fibers," Recycling Symp., New Orleans, TAPPI Press, Atlanta, 379-385.

Mocchiutti, P., Zanuttini, M., Citroni, M., and Inalbon, M. C. (2006). "Effects of drying conditions and of the existing cationic starch in liner paper recycling," Cellulose Chem. Technol. 40(1-2), 87-91.

Moyers, B. M. (1991). "Diagnostic sizing loss problem solving in alkaline systems," Proc. TAPPI 1991 Papermakers Conf., TAPPI Press, Atlanta, 425-432.

Nanko, H., and Ohsawa, J. (1989). "Mechanisms of fiber bond formation," in Fundamentals of Papermaking, Vol. 2, 783-830, Waveney Print Services, Suffolk, UK.

Nazhad, M. A. (2004). "The role of fiber surface condition on paper strength," Proc. The 2004 Progress in Paper Physics Seminar, Trondheim, Norway, 91-94.

Nazhad, M. M. (2004). "The influence of refining energy and intensity on enhancing the bonding potential of an OCC pulp," Appita J. 57(3), 191-198.

Nazhad, M. M. (2005). "Recycled fiber quality - A review," J. Ind. Eng. Chem. 11(3), 314-329.

Nazhad, M. M., and Paszner, L. (1994). "Fundamentals of strength loss in recycled paper," Tappi J. 77(9), 171-179.

Neimo, L. (1999). Papermaking Chemistry, Papermaking Science and Technology series, No. 4, Fapet Oy, Helsinki.

Newman, R. H., and Hemmingson, J. A. (1997). "Cellulose cocrystallization in hornification of kraft pulp,” Proc. 1997 ISWPC, Paper 01, 1-4.

Nguyen, X. T., Shariff, A., Earl, P. F., and Eamer, R. J. (1993). "Bleached pulps for printing and writing papers from old corrugated containers," Prog. Paper Recycling $3(2), 25-32$.

Ogden, R. W. (1999). "Rehydration of once-dried fiber," US Pat. 5,825,218.

Okayama, T. (2002). "The effects of recycling on pulp and paper properties," Kami Pa Gikyoshi/Japan Tappi Journal 56(7), 62-68.

Oksanen, T., Buchert, J., and Viikari, L. (1997). "The role of hemicelluloses in the hornification of bleached kraft pulps," Holzforschung 51(4), 355-360.

Oye, R., Okayama, T., Yamazaki, T., and Yoshinaga, N. (1991). "Changes of pulp fiber cell wall by recycling," ler Forum Recherche sur le Recyclage (1st Research Forum on Recycling), October 29-31, 1991, Toronto , Ontario , CPPA, Montreal, Quebec, Canada, 191-195.

Paavilainen, L. (1993). "Conformability - flexibility and collapsibility - of sulfate pulp fibers," Paperi Puu 75(9-10), 896-702.

Page, D. H. (1969). "A theory for the tensile strength of paper," Tappi 52(4), 674-681.

Page, D. H., Seth, R. S., Jordan, B. D., and Barbe, M. C. (1986). "Curl, crimps, kinks, and microcompressions in pulp fibers - Their origin, measurement and significance," in Punton, V. (ed)., Papermaking Raw Materials. Transactions of the $8^{\text {th }}$ Fundamental Research Symposium held at Cambridge, Sept. 1985, Mechanical Engineering Publications Ltd., London, Vol. 1, 183-277.

Page, D. H., and Tydeman, P. A. (1962). "A new theory of the shrinkage, structure, and properties of paper," in Bolam, F., Ed., Transactions of the Oxford Symposium, Tech. Sect. British Paper and Board Makers Assoc., London, 397-425. 
Pala, H., Lemos, M. A., Mota, M., and Gama, F. M. (2001). "Enzymatic upgrade of old paperboard containers," Enzyme Microbial Technol. 29(4-5), 274-279.

Park, S., Venditti, R. A., Jameel, H., and Pawlak, J. J. (2006a). "Changes in pore size distribution during the drying of cellulose fibers as measured by differential scanning Calorimetry," Carbohydrate Polymers 66(1), 97-103.

Park, S., Venditti, R. A., Jameel, H., and Pawlak, J. J. (2006b). "A novel method to evaluate fiber hornification by high resolution thermogravimetric analysis," Appita J. 59(6), 481-485.

Park, S., Venditti, R. A., Jameel, H., and Pawlak, J. J. (2006c). "Hard to remove water in cellulose fibers characterized by high resolution thermogravimetric analysis Methods development," Cellulose 13(1), 23-30.

Paulapuro, H. (2000). Papermaking. Part 1, Stock Preparation and Wet End, Papermaking Science and Technol. Ser., No. 8, Fapet Oy, Helsinki.

Pekkarinen, T. (1985). "Fractionation of OCC waste paper with a pressure screen," Proc. TAPPI 1985 Pulping Conf., TAPPI Press, Atlanta, 37-39.

Peng, Y. X.., Valade, J. L., and Law, K. N. (1994). "Effects of recycling and blending of virgin fibers on paper properties," China Pulp and Paper 13(2), 3-9.

Peterson, D., Qi, D., and Zhang, S. (2000). "Effects of fines concentration on mechanical properties of recycled paper," Proceedings of the 2000 TAPPI Recycling Symposium, Mar 5-8 2000, Washington, DC, Vol. 2, 653-661.

Phipps, J. (1994). "Effects of recycling on the strength properties of paper," Paper Technol. 35(6), 34-40.

Pruden, B. (2005). “The effect of fines on paper properties," Paper Technol. 46(4), 1926.

Putz, H.-J. (1996). "How often can wastepaper be recycled?" Allg. Papier-Rundschau 120(31), 851-852.

Putz, H.-J. (2007). "Recyclability of paper and board products," International Paperworld IPW (4), 37-43

Putz, H.-J., Muller-Mederer, C., Kuhn, J., and Garber, W. (2003). "Recyclability of printed coated papers," International Paperworld IPW 12, 35-40.

Pycraft, C. J. H., and Howarth, P. (1980). "A method of measuring enzyme degradation of cellulose fibers," Paper Technol. Ind. 21(9), 283-285.

Pycraft, C. J. H., and Howarth, P. (1980). "Does better paper mean worse waste paper?" Paper Technol. Ind. 21(12), 321-324.

Qian, L., He, B., Huang, Y., and Zhan, H. (2005). "Effects of recycling on mason pine pulp properties," Prog. Paper Recycling 14(3), 19-23.

Rao, R., and Kuys, K. (1995). "Surface chemistry of fibers in recycling of newsprint and magazines," Proc. 8th International Symposium on Wood and Pulping Chemistry, June 6-9, 1995, Helsinki, Finland: Proceedings, 3: Poster Presentations, 261-266.

Retulainen, E., Luukko, K., Fagerholm, K., Pere, J., Laine, J., and Paulapuro, H. (2002). "Papermaking quality of fines from different pulps - the effect of size, shape, and chemical composition," APPITA J. 55(6), 457-460.

Roberts, J. C. (ed.), Paper Chemistry, $2^{\text {nd }}$ Ed., Blackie, Chapman and Hall, London.

Roberts, J. C., Au, C. O., Clay, G. A., and Lough, C. (1986). "The effect of C ${ }^{14}$-labelled cationic and native starches on dry strength and formation," Tappi J. 69(10), 88-93. 
Robertson, A. A. (1964). "Some observations on the effects of drying papermaking fibers," Pulp Paper Mag. Can. 65(3), T161-T168.

Roffael, E., and Schaller, K. (1971). "Influence of thermal treatment on cellulose," Holz als Roh-und Werkstoff 29(7), 275-278.

Rojas, O. J. (2004). "Surfactantes no destintamento do paper (Surfactants in Paper Deinking)," O Papel 65(12), 62.

Rojas, O. J., Dedinaite, A., Byrd, M. V., Hubbe, M. A. and Claesson, P. M. (2005). “On the origins of adhesion in papermaking systems," (S. J. I'Anson, ed.), 2: 1351-1378, Digital Books Logistics Ltd, Peterborough, UK.

Rossi, S., Osterberg, F., Eriksson, L., and Kouppa, H. (1994). "Effect of recycling of the fiber on the properties of the fiber and of the paper," Industria della Carta 32(5), 241250.

Ruffini, G. (1966). "Improvement in bonding of wood pulps by the presence of acidic groups," Svensk. Papperstidn. 69, 72-76.

Rundöf, M., Htun, H., Höglund, H., and Wågberg, L. (2000). "Mechanical pulp fines of poor quality - Characteristics and influence of white water," J. Pulp Paper Sci. 26(9), 308-316.

Santos, J. M. R. C. A., Portugal, A., and Guthrie, J. T. (2001). "Characterization of the surface of a cellulosic multi-purpose office paper by inverse gas chromatography," Cellulose 8(3), 217-224.

Scallan, A. M. (1977). "The accommodation of water within pulp fibers," in Fiber-Water Interactions in Papermaking, Trans. Symp. Oxford, Tech. Div. British Paper and Board Industry Federation, London, Vol. 1, 9-29.

Scallan, A. M. (1998). "Mechanisms of hornification," Proc. Improvement of recyclability and the recycling paper industry of the Future, A. Blanco, C. Negro, I Gaspar, M. C. Monte, and J. Tijero, (eds.), COST Action E1, La Palmas de Gran Canaria, 24-26 Nov., 312-314.

Scallan, A. M., and Carles, J. E. (1972). "The correlation of the water retention value with the fiber saturation point," Svensk Papperstidn. 75(7), 699-703.

Scallan, A., and Tigerstrom, A. C. (1991), "Elasticity of fiber wall; Effects of pulping and recycling," Proc. CPPA $1^{\text {st }}$ Res. Forum on Recycling, CPPA, Montreal, 149-154.

Scott, W. E. (1989). "A survey of the various contaminants present in recycled wastepaper white water systems," Proc. 1989 Contaminant Problems and Strategies in Wastepaper Recycling, TAPPI Press, Atlanta, 69-80.

Scott, W. E. (1996). Principles of Wet End Chemistry, TAPPI Press, Atlanta.

Scott, W. E., Abbott, J. C., and Trosset, S. (1995). Properties of Paper: An Introduction, TAPPI Press, Atlanta.

Shao, S. Y., and Hu, K. T. (2002). "Hornification of recycled fiber," China Pulp Paper (2), 57-60.

Shao, Z. and Li, K, (2006). "Surface lignin and interfibre bonding," Journal of Wood Chemistry and Technology, 26(3), 231-244.

Shen, W., Filonanko, Y., Truong, Y., Parker, I. H., Brack, N., Pigram, P., and Liesegang, J. (2000). "Contact angle measurement and surface energetics of sizes and unsized paper," Colloids Surf. A 173(1), 117-126. 
Shrinath, A., Szewczak, J. T., and Bowen, I. J. (1991). "A review of ink-removal techniques in current deinking technology," Tappi J. 74(7), 85-93.

Siewert, W. H. (1996). "Potential for improving the quality of waste paper stock," Wochenbl. Papierfabr. 124(6), 217-220.

Singh, S., and Roy, D. N. (1996). "The effect of recycling on chemical properties of the thermomechanical pulp," J. Wood Chem. Technol. 16(4), 421-437.

Sjöström, L., and Ödberg, L. (1997). "Influence of wet-end chemicals on the recyclability of paper," Papier 51(6A), V69-V73.

Slavic, I., and Kucerova, M. (1967). "Formation of lactone bonds in cellulose during acidification and drying," Faserforsch Techtiltech. 18, 396-397.

Sohn, S. D., and Paik, K. H. (2006). "Effects of initial calendering on physical properties of recycled pulp handsheets," J. Industrial Eng. Chem. 12(3), 460-468.

Somwang, K., Enomae, T., Isogai, A., and Onabe, F. (2002). "Changes in crystallinity and re-swelling capacity of pulp fibers by recycling treatment," Kami $\mathrm{Pa}$ Gikyoshi/Japan Tappi Journal 56( 6), 103-109.

Somwang, O., Enomae, T., and Onabe, F. (2001). "Effect of fiber hornification in recycling on bonding potential at Interfiber crossings: Confocal laser-scanning microscopy," Kami Pa Gikyoshi/Japan Tappi Journal 56(2), 79-85.

Stauffer, T., Venditti, R. A., Gilbert, R. D., Kadla, J. F., and Montero, G. (2001). "The removal of wax from wax containing old corrugated containers using supercritical $\mathrm{CO}_{2}$, , J. Appl. Polymer Sci. 81, 1107-1114.

Steadman, R., and Luner, P. (1985). "The effect of wet fiber flexibility on sheet apparent density," in Papermaking Raw Materials, Trans. $8^{\text {th }}$ Fundamental Res. Symp., Oxford, Punton, V. (ed.), Mechanical Engineering Publ. Ltd., London, Vol. 1, 311 337.

Stone, J. E., and Scallan, A. M. (1966). "Influence of drying on the pore structures of the cell wall," in Consolidation of the Paper Web, Trans. Symp. Cambridge, Sept. 1965, F. Bolam (ed.), Tech. Sec. British Paper and Board Makers' Assoc. Inc, London, Vol. 1, 145-174.

Stone, J. E., and Scallan, A. M. (1968). "A structural model for the cell wall of waterswollen wood pulp fibers based on their accessibility to macromolecules," Cellulose Chem. Technol. 2(3), 343-358.

Stürmer, L., and Göttsching, L. (1979). "Physical properties of secondary fiber pulps under the influence of their previous history. Part 3: Influence of the paper manufacturing process," Wochenbl. Papierfabr. 107(3), 69-76.

Sumi, Y., Hale, R. D., and Rånby, B. G. (1963). "The accessibility of native cellulose microfibrils" Tappi 46(2), 126-130.

Sundberg, K. E., Sundberg, A. C., Thornton, J. W., and Holmbom, B. R. (1998). "Pectic acids in the production of wood-containing paper," Tappi J. 81(7), 131-136.

Sundholm, J. (ed.) (1999). Mechanical Pulping, Papermaking Science and Technology ser. No. 5, Fapet Oy, Helsinki.

Swanson, J. W., and Cordingly, S. (1959). "Surface chemical studies on pitch. II. The mechanism of the loss of absorbency and development of self-sizing in papers made from wood pulp," Tappi 42(10), 812-819. 
Szwarcsztajn, E., and Przybysz, K. (1976). "Investigation on changes in the properties of recycled pulp fractions," Cell. Chem. Technol. 10, 737-749.

Szwarcsztajn, E., and Przybysz, K. (1978). "The role of pulp fractions and processing variables in recycling," in Fiber-Water Interactions in Papermaking, Techn. Div. British Paper and Board I. F., London, 857-876.

Tam Doo, P. A., and Kerekes, R. J. (1982). “The flexibility of wet pulp fibers," Pulp Paper Can. 83(2), T37-T42.

Teachman, J. J., Williams, M. W., and Qi, D. (1998). "Effect of recycling of thermomechanical pulps on sheet surface properties and fines content," Prog. Paper Recycling 7(4). 11-19.

Tschirner, J., Barsness, J., and Keeler, T. (2007). "Recycling of chemical pulp from wheat straw and corn stover," BioRes. 2(4), 536-543.

Tschirner, U., Cao, B., and Ramaswamy, S. (1998). "Study of changes in wet-fiber flexibility and surface condition of recycled fibers," Proc. TAPPI 1998 Recycling Symposium: Proceedings, March 8, New Orleans, LA, TAPPI Press, Atlanta, 149162.

Tschirner, U., and Wang, D. (1998). "Hydrogen peroxide bleaching of mixed recycled fiber," Prog. Paper Recycling 8(1), 15-22.

Thode, E. F., Chase, A. J., and Hu, Y. (1955). "Dye adsorption on wood pulp. IV. Note on effect of drying of pulp on specific dye adsorption," Tappi 38(2), 88-89.

Torgnysdotter, A., and Wågberg, L. (2006). "Tailoring of fiber/fiber joints in order to avoid the negative impacts of drying on paper properties," Nordic Pulp Paper Res. J. 21(3), 411-418.

Tze, W. T., and Gardner, D. J. (2001a). "Swelling of recycled wood pulp fibers: Effect on hydroxyl availability and surface chemistry," Wood Fiber Sci. 33(3), 364-376.

Tze, W. T., and Gardner, D. J. (2001b). "Contact angle and IGC measurements for probing surface-chemical changes in the recycling of wood pulp fibers," J. Adhes. Sci. Technol. 15(2), 223-241.

Van Wyk, W., and Gerischer, G. (1982). "The influence of recycling on the strength properties of machine made paper," Paperi Puu 64(9), 526-533.

Venditti, R. A., Chang, H.-M., and Copeland, K. L. (2005). "Evaluation of various adhesive contaminant (stickies) analysis methods: Tracking stickies concentrations across unit operations in old corrugated container recycling plants," Prog. Paper Recycling 14(2), 9-16.

Venditti, R. A., Kadla, J. F., Gilbert, R. D., Jameel, H., and Chang, H.-M. (2001). “Three novel wax removal methods for wax containing old corrugated containers: Carbon dioxide extraction, kraft pulping, and agglomeration," TAPPI Pulping Conf. Proc., Seattle, WA, TAPPI Instant Reference.

Venditti, R., Gilbert, R., Zhang, A., and Abubakr, S. (2000). "The effect of release liner materials on adhesive contaminants, paper recycling and recycled paper properties," Proc. 2000 TAPPI Recycling Symp., Mar 5-8 2000, Washington, DC, TAPPI Press, Atlanta, Vol. 2, 579-591.

Vinson, K., Byrd, M., Jameel, H., Chang, H. M., Venditti, R. A., and Heitmann, J. A. (2001). "Fiber fractionation of mixed office waste for production of value-added products," TAPPI Pulping Conf. Proc., Seattle, 1116-1129. 
Wadehra, L., and Manley, R. St. J. (1965). "Recrystallization of amorphous cellulose," J. Appl. Polym. Sci. 9(7), 2627-2630.

Wågberg, L., Forsberg, S., Johansson, A., and Juntti, P. (2002). "Engineering of fibre surface properties by application of the polyelectrolyte multilayer concept. Part I:

Modification of paper strength," J. Pulp Paper Sci. 28 (7), 222-228.

Wågberg, L., and Ödberg, L., (1989). "Polymer adsorption on cellulosic fibers," Nordic Pulp Paper Res. J. 4(2), 135-140.

Wahren, D., and Berg, B. (1972). "Reuse of cellulose fibers," Svensk Papperstidn. 75(4), 125-130.

Walecka, J. A. (1956). "An investigation of low degree of substitution carboxymethylcelluloses," Tappi 39(7), 458-463.

Wang, X., Maloney, T. C., and Paulapuro, H. (2003). "Internal fibrillation in never-dried and once-dried chemical pulps," Appita J. 56(6), 455-459.

Watanabe, A., and Mitsuhiro, S. (2005). "A report on an investigation of recyclability of troublesome paper materials in the paper recycling process," Kami Pa Gikyoshi/ Japan Tappi Journal 59(7), 17-32.

Webb, L. J. (1992). "Secondary fiber and wet end chemistry," Proc. The Chemistry of Papermaking Conf., Pira International, Leatherhead, Surrey, UK, 1-18.

Weise, U. (1998). “Hornification - Mechanisms and terminology," Paperi Puu 80(2), $110-115$.

Weise, J., Hiltunen, E., and Paulapuro, H. (1998). "Hornification of cellulosic pulp and measures to reverse it," Papier (10A), V14-V19.

Weise, U., Maloney, T., and Paulapuro, H. (1996). "Quantification of water in different states of interaction with wood pulp fibers," Cellulose 3(4), 189-202.

Weise, U., and Paulapuro, H. (1996). "The relationship between fiber shrinkage and hornification," Papier 50(6), 328-333.

Weise, U., and Paulapuro, H. (1998). "Relation between fiber shrinkage and hornification," Prog. Paper Recycling 7(3), 14-21.

Weise, U. and Paulapuro, H. (1999). "Effect of drying and rewetting cycles on fiber swelling," J. Pulp Paper Sci. 25(5), 163-166.

Welf, E. S., Venditti, R. A., Hubbe, M. A., and Pawlak, J. J. (2005). "The effects of heating without water removal and drying on the swelling as measured by water retention value and degradation as measured by intrinsic viscosity of cellulose papermaking fibers," Prog. Paper Recycling 14(3), 1-9.

Whang, H.-S., and Gupta, B. S. (2000). "Surface wetting characteristics of cellulosic fibers," Textile Res. J. 70(4), 351-358.

Williams, J. C. (1980). "Retaining the strength of secondary fibers with alkaline calcium carbonate fillers," Paper Trade J. 164(22), 33-34.

Wistara, N., and Young, R. A. (1999). "Properties and treatments of pulps from recycled paper. Part 1. Physical and chemical properties of pulps," Cellulose 6(4), 291-324.

Xu, Y., Yang, C. Q., and Chen, C.-M. (1999). "Wet reinforcement of paper with highmolecular-weight multifunctional carboxylic acid," Tappi J. 82(2), 150-156.

Yamagishi, Y., and Oye, R. (1981). "Influence of recycling on wood pulp fibers Changes in properties of wood pulp fibers with recycling," Japan Tappi J. 35(9), 787 797. 
Youn, H. J., Chin, S. M., Choi, I. S., and Kim. J. Y. (2007). "Fractionation of KOCC for better utilization - Effect of screen design parameter and reject flow rate on flocculation efficiency," IPPTA: Quarterly Journal of Indian Pulp and Paper Technical Association 19(1), 97-99.

Zhang, M., Hubbe, M. A., Venditti, R. A., and Heitmann, J. A. (2001). "Effect of chemical pretreatments of never-dried pulp on the strength of recycled linerboard," Proc. 2001 TAPPI Papermakers Conf., TAPPI Press, Atlanta, digital doc.

Zhang, M., Hubbe, M. A., Venditti, R. A., and Heitmann, J. A. (2002). "Can recycled kraft fibers benefit from chemical addition before they are first dried"? Appita J. 55(2), 135-144.

Zhang, M., Hubbe, M. A., Venditti, R. A., and Heitmann, J. A. (2004). "Effects of sugar addition before drying on the wet flexibility of redispersed kraft fibers," J. Pulp Paper Sci. 30(1), 29-34.

Zhang, M., Hubbe, M. A., Venditti, R. A., and Heitmann, J. A. (2004). "Refining to overcome effects of drying unbleached kraft fibers in the presence or absence of sugar," Prog. Paper Recycling 13(2), 5-12.

$\mathrm{Xu}, \mathrm{Y}$., Li, K., and Zhang, M. (2007). "Lignin precipitation on pulp fibres in ethanol based organosolv pulping," Colloids and Surfaces A: Physicochemical and Engineering Aspects, 301(1-3), 255-263. 